\title{
ACCOUNTING AND THE EXAMINATION: A GENEALOGY OF DISCIPLINARY POWER*
}

\author{
KEITH W. HOSKIN \\ University of Warwick \\ and \\ RICHARD H. MACVE \\ University College of Wales, Aberystwyth
}

\begin{abstract}
Historical elaboration of Foucault's concept of "power-knowledge" can explain both the late-medieval developments in accounting technology and why the near-universal adoption of a discourse of accountancy is delayed until the nineteenth century. It is the disciplinary techniques of elite medieval educational institutions - the new universities and their examinations - that generate new power-knowledge relations. These techniques embody forms of textual rewriting (including the new "alphanumeric" system ) from which the accounting advances are produced and "control" is formal ised. "Double-entry" is an aspect of these rewritings, linked also to the new writing and rewritings of money, especially the bill of exchange. By the eighteenth century accounting technologies are feeding back in a general way into educational practice (e.g. in the deployment of "book-keeping" on pupils) and this culminates in the introduction of the written examination and the mathematical mark. A new regime of "objective" evaluation of total popula. tions, made up of individually "calculable" subjects, is thereby engendered and then extended - apparently first in the U.S. railroads - into modern comprehensive management and financial accounting systems ( systems of "accountability" embodying Foucault's "reciprocal hierarchical observation" and "normalising judgement"), while written examinations become used to legitimate the newly autonomous pro. fession of accountancy.
\end{abstract}

It is inadequate to attempt to explain the significance of accounting in modern society by iden. tifying any clear link between its use and the improvement of "rational economic decision taking" (Burchell et al., 1980). Yamey (e.g. 1964 ) has refuted "the Sombart thesis" and shown that there is no clear link to be found between the rise of Renaissance capitalism and the invention of "double-entry" bookkeeping and one can similarly refute suggestions that the lack of modern accounting techniques in itself exp- lains the apparent lack of economic rationality in antiquity (Macve, 1985). How then is one to explain the modern significance of accounting and the ample rewards that accrue to its practitioners? This is a complex question but in this paper we propose to suggest how a history of accounting and an understanding of its power in modern society might be written in terms of Michel Foucault's theory of "power-knowledge" relations.

Our main argument focuses on two separate

* We gratefully acknowledge the helpful discussion and criticism of an earlier draft of this paper provided by Simon Archer. David Cooper. Neil Garrod. David Gwilliam. Trevor Hopper, Anthony Hopwood and Gareth Williams. They would of course not necessarily agree with the viex's expressed in it, nor are they in any way responsible for its remaining defects. 
developments: the invention of a particular accounting system, double-entry, taking place in the thirteenth and fourteenth centuries, and the much later social development of a discourse of accountancy, in the nineteenth century, wherein the double-entry system gains widespread adoption (and elaboration) and a professional network of accountants appears. We depart from the conventional view of this latter development (which normally links it in some general way to the Industrial Revolution), and concomitantly advance an explanation of the former development, in power-knowledge terms, as part of a general transformation in writing. We shall suggest, in order to explicate the problem of the interrelation between power and knowledge, that it is necessary to explore how these two major transformations in the practice of accounting are linked to transformations in the techniques for organising and creating knowledge developed by pedagogues - trans formations which enable the emergence of new forms of power. In particular we focus on the examination as a technique of knowledge and a technology of power.

\section{"POWER-KNOWLEDGE" AND THE EXAMINATION}

First, some introductory explanation of the way in which we are developing Foucault's views on power-knowledge relations is needed. Foucault himself saw a shift in his work from an archaeology of knowledge structures, for instance the epistemes or discourses analysed in The Order of Things (Foucault, 1970) to a genealogy of knowledge practices as in Discipline and Punish (Foucault, 1977) and in his last volumes on the history of sexuality (Foucault, $1979,1984 a, b)$. In this shift, following Nietzsche, he theorised power as'something positive: not as repression or suppression, but as a set of practices which could be specified and which positively produced ways of behaving and predispositions in human subjects: indeed the most pervasive power is that which makes its subjects cooperate and connive in their subjection to it

As a general statement, Foucault came to feel that knowledge practices were always also practices of power, or to put it slightly differently, that knowledge relations always implicated power relations, and vice versa, and that the interrelations between them could and should be specified so as to understand the present and our more, and less, possible futures. These interrelations he summed up in the term "savoirpouvoir", usually translated as "power-know. ledge".

In his first major genealogical work, Discip. line and Punish (Foucault, 1977) he contended that the means of social control have shifted from an older punishment on the body to a disciplining of the person (and its correlative reflexive form, self-discipline). And at the heart of the book he described the implementation of this new discipline in terms of a micro-technology of power, the "means of correct training" whose finest embodiment is the examination (1977, pp. 170-194).

In the context of the school this "slender technique" enables a systematic surveillance and observation of pupils to take place, especially as it becomes a regular means of testing performance and keeping students "up to the mark". The school becomes a "sort of apparatus of uninterrupted examination". Simultaneously there is produced a new power of judgement over pupils. As mathematical marks are awarded, students become subject to a system of "micropenality", or "penal accountancy", in the shape of good marks and bad: at first awarded for academic work, these are extended to cover all aspects of behaviour and performance, and so the examination "leaves behind it a whole meticulous archive constituted in terms of bodies and days" in the form of written performance and records. This material makes it possible to generate a "history" of each individual and simultaneously to classify the individuals en masse into categories, and eventually into "populations" with norms.

The examination "normalises" at the same time as it makes each individual into a case with 
a "case-history" (Foucault, 1977, pp. 184-187). It introduces a new principle of individual accountability by affording a numerical "objective" judgement on the person, thus "substituting for the individuality of the memorable man that of the calculable man" ( $p .193$ ). The power of the examination, and more generally of disciplinary power, lies in its double aspect. It "combines the deployment of force and the establishment of truth. . . The superimposition of the power relations and the knowledge relations assumes in the examination all its visible brilliance".

There were problems with this initial formulation, as Foucault himself (Foucault, 1982) came to realise. His early work down to Discipline and Punish concentrated mainly on what he called the "âge classique" of the seventeenth and eighteenth centuries; but his more recent work came to acknowledge that the development in the "âge classique" cannot be understood outside a much longer history, which, after Heidegger and Derrida (Derrida, 1976), has become known as the history of the Logos, i.e. the history of the "Word", in all its ramifications, in Western culture. We are suggesting that this history should be approached through the uriting of the "Word" as practised in pedagogic settings.

Even that key Foucaldian term "discipline" has a pedagogic history stretching back to Graeco-Roman antiquity. It derives from an Indo-European root, -da-, which is the root for both the Greek pedagogic term didasko (teach) and the Latin (di)disco (learn); and disciplina itself already has in classical Latin the double sense of knowledge (knowledge-system) and power (discipline of the child, military discipline). In the 13th century, in the context of the new universities, it comes to have a more specific usage. denoting the new academic "disciplines" of Law and Theology (Evans, 1981 ); and in the sixteenth and seventeenth centuries pedagogic systems are written down (e.g. in the Jesuit Ratio Studiorum and the Christian Brothers' Conduct of the Schools) in order to prescribe meticulous plans of surveillance and behavioural control. All this forms an essential pre-history to the fully-fledged system of "discip- linary power", and our point is that one has to look to the work of pedagogues in educational settings to discover it.

Similarly, with the examination, the educational context has a special priority which Foucault's work does not fully bring out. The technique, we would argue, discovers its modern power when, around 1800 , it becomes written and adopts mathematical grading (Hoskin, 1979), but it has its own earlier history which begins with the invention of the first examinatorial institution in western history, the university. If the late eighteenth century moment marks a discontinuity when a new power-knowledge configuration appears (as we shall argue it does), we would argue it must be traced back to an earlier moment of discontinuity when new powerknowledge possibilities developed in and around the nascent university. However, while we would maintain that this is a necessary elaboration upon Foucault's work, our main point remains within a tradition which is recognisably Foucauldian: our thesis is that examination, discipline and accounting are historically bound tugether as related ways of writing the world (in texts, institutional arrangements, ultimately in persons ) into new configurations of power.

\section{THE PROBLEMATIC HISTORY OF ACCOUNTING}

We should start from the problems posed by conventional accounting history. First it is now clear that full-scale systematic accounting (both in the refined single-entry systems like chargedischarge, and especially in the new doubleentry systems) is developed in the thirteenth and fourteenth centuries; it is not to be found in antiquity (Ste. Croix, 1956; Macve, 1985), nor in Arabic culture (Udovitch, 1979). Second it is clear that it remains sporadically used until the nineteenth century, and that in addition modern phenomena such as cost accounting and a corporate managerialism based on systematic forms of accountability (and indeed an independent profession of accountancy) only develop then. Yet no coherent explanation has heen advanced 
which covers both the first development and the long delay until the second. That is something a power-knowledge analysis may offer, building on a number of findings and observations not previously linked together.

\section{PEDAGOGIC RE-WRITINGS AND ARABIC NUMERALS}

On the first problem, St. Croix (1956, pp. 61 ff., esp. 64-66) suggested that in a sense doubleentry was impossible in antiquity in the absence of arabic numerals. Ancient arithmetical notations lacked a zero and so afforded no means of writing numbers with place-value; hence columnar arrangement offered no special advantage and accordingly we find no systematic use of opposed columns and little tabulation within columns, let alone a systematic employment of the journal-ledger dyad which is found from the thirteenth century on. Clearly arabic numerals are of a crucial importance; they allow a new interrelated writing of word and number in what has been described as an "alphanumeric" system. For arabic numerals are precisely analogous to the alphabet in being a Logos - a Logos of number: like the alphabet they deploy an economic number of signs (ten) which allow a nonambiguous writing and deciphering of arithmetical statements, and (in conjunction with the alphabet ) produce an increasingly complex range of such statements (by the seventeenth century we find algebra using the $x, y$ notation, logarithms, decimals - where the grammatical punctuation point is added to numbers - and calculus).

But arabic numerals alone do not explain the sudden proliferation of new ways of writing accounts in the thirteenth century; by which we mean both the internal writing of texts into columnar, gridded bilateral structures and the production of a new range of secondary texts journals, ledgers and increasing numbers of subordinate books such as customer accounts, sales books, foreign exchange books and the confidential libri segreti discussed in detail by Raymond de Roover (de Roover, 1948, 1963.
1974). A range of recent works (e.g. Clanchy, 1979; Murray, 1978; Rouse \& Rouse, 1982; Landes, 1983; Saenger, 1982; Hoskin, 1984) now enable us to demonstrate how a fundamental rewriting of writing is involved in this transformation, a re-writing which predates the introduction of arabic numerals and enables them to be deployed as part of a new alphanumeric discourse. (This perhaps also explains why they are not previously so used in Arab culture.)

This re-writing begins, as Saenger (1982) points out, at the simplest level, with the introduction into alphabetic texts of word-separation, something which ancient texts do not have. Its early development appears to be the work of the religious pedagogues of the Latin West in the seventh and eighth centuries (Saenger, 1982, p. 377 ), either as a strategy of desperation because their Latin was so weak or because Latin was for them an essentially visual language, learned primarily from vocabularies and grammars. In any event, a visual fractioning of texts became commonplace and by the eleventh century pedagogues were developing techniques for rewriting texts into new configurations. Rouse $\&$ Rouse (1982, p. 203) mention three: the Elementarium of Papias (c. 1050), the "first alphabetically arranged work of any magnitude", which used marginal letters of various sizes to mark when the first, second and third letters of words listed changed; a "primitive subject index" devised by Cardinal Deusdedit for searching his collection of canon law texts ( $c$. 1085 ); and the use of marginal indexing symbols in Gilbert of Poitier's Commentary on the Psalms. This kind of systematic ordering and gridding is unknown in antiquity. By 1200 it will become endemic in the pedagogic world, and begin to manifest its power-knowledge implications.

In this regard it is important to stress that changes begin to take place across a wide spectrum of phenomena, all of which coalesce in creating a new sense of gridded order and control.David Landes (1983, pp. 58 ff.) points out that the first sustained interest in time measure. ment appears among the same network of religious pedagogues (he cites Bede's de Temporum 
Ratione and the "great volume of tables, charts, discussion and diagrams" to be found in medieval texts on time); and he makes an observation which underscores the secondary role played by technical breakthroughs like arabic numerals per $s e$ in the new discourse of order: "The clock did not create an interest in time measurement; the interest in time measurement led to the invention of the clock": the medium, in other words, is not in itself the message. Alongside this interest in time measurement there developed a concern for spatial organisation for order and surveillance, most clearly evidenced in the Plan of St. Gall: the design of the monastery as a self-enclosed total institution with cellular division and separation of religious buildings from dormitories and from working and eating areas. The Plan ( $c .800$ ) became the model for western monasticism, as well as an architectural expression of the regulated life drawn up in the Rule of St. Benedict. In sum, the word, space and time were all being re-written in interconnected ways, and the point is that this general development took place only in the Latin West, beginning in the world of religious pedagogues.

One final observation which is significant for the great take-off of the twelfth century. It is the Latin West which introduces a change in the ecology of alphabetic writing, when for the first time an alphabet is taken over without alteration of letter form for the writing of vernaculars. As Italian, Provençal, French, English etc. become written in the Latin alphabet the scope for order and interconnection beyond the learned world (and for the learned to extend their power into vernacular settings ) is increased immeasurably.

\section{ALPHANUMERIC WRITING: A NEW TEXTUALITY}

Our point - necessarily compressed - is this. New modes of re-writing the social world (and its individual subjects) become feasible in the West from around 700 A.D. But their social impact - their power - is extremely circumscribed until around 1100 ; Rouse \& Rouse
(1982, p. 203) for instance point out that Papias's ordering technique is "far ahead of its time" and is ignored by copyists for over 100 years. In power-knowledge terms, it is only when a new knowledge elite appears, centred around the nascent universities, that these new modes coalesce into a significant new social discourse. That new elite, the clerks and masters, perform a double function. They produce a vast new range of pedagogic re-writings of texts, i.e. techniques which grid texts both externally and internally in the service of information-retrieval and knowledge-production. And as part of the process of knowledge-production they begin to write handbooks on the use of arabic numerals, at first on the use of the abacus and then on the pen-and-paper system known as the Algorism (Evans, 1977). Thus it is that arabic numerals enter, and then help to shape (ultimately even to take over), a discourse committed to ordering and gridding of a kind never known before.

The emergence of an "arithmetical mentality" in the West is discussed by Murray (1978, ch. 7 and 8 ), who helps to lay the old ghost that it is principally due to the merchant: his role is "not that of a pioneer or even a patron of pioneers" (p. 194), but of leading beneficiary in the late twelfth century. Before then the abacus had been spreading, since around 1000 A.D. and along with a new sense of numerical power, via a growing range of treatises written by clerical pedagogues; where earlier works like Alcuin's Propositions (c. 800 A.D.) had computed up to 9000 , Gerbert's treatise (c. 1000 A.D.) "launches in with multiplication and division-rules for products up to $10^{10 "}$ (Murray, 1978, p. 164). Haskins (1924) long ago drew attention to the introduction of the abacus into the English Exchequer as evidenced by a treatise by the royal clerk Thurkill (c. 1100 A.D.). Thurkill was a product either of the schools of Laon or Lorraine and was sufficiently au fait with mathematical issues to produce a further treatise on the conversion of marks to pounds. By the later twelfth century this social group has acquired a name - moderni - and a reputation to match: Neil of Longchamp (c. 1180) writes of Burnel the Ass who goes to Paris and Bologna to 
become Magister Burnellus so that "wherever he goes people will call out 'The Master cometh' and corporation presidents will take his counsel as their own" (Clanchy, 1975, p. 681 ).

The re-writing undertaken by the twelfth century pedagogues needs to be seen as a new kind of textuality. Saenger identifies a central aspect of this (1982, pp. $386 \mathrm{ff}$ ): a shift from reading aloud (the prestigious mode of reading in antiquity and monastic culture) to silent read. ing, and concomitantly a shift in composition from dictation to writing. The scholars of the cathedral schools and universities begin to use visualist metaphors both to denote reading (e.g. videre, inspicere) and composition (scribere for dictare) (Saenger, 1982, pp. 386-389). In Roman Law, Canon Law and Theology a new "critical reading" (named by Abelard in his Sic et Non, c. 1120 A.D., as "inquisitio") begins to be developed, a reading which depends upon the re-ordering and cross-referencing of authoritative primary texts - Justinian's Corpus, the Canonical Collections and the Bible respectively. ${ }^{1}$

By the thirteenth century this enterprise of rewriting the primary text both internally and externally quite clearly produces a new textuality. Internally the text has become a grid: chapter and verse division, paragraphing, chapter headings and intricate marginal symbols marking the glosses all serve to make the text visually accessible; but they do more, for the text is no longer read straight through, but in relation to other passages and other texts. Its signs no longer speak for themselves but through other signs from elsewhere. And that kind of reading is facilitated - and constantly extended - by the production of new kinds of external secondary writing which grow directly out of the gridding procedures (where they do not actively engender them ) - one thinks of the growing use of alphabetical listing, and the appearance of indexes and concordances. Both as readers and writers, people can begin to have a new relation to texts.

Rouse \& Rouse make a particularly telling point about this re-writing for information retrieval, namely that a new principle of alphabetization is articulated. They comment (1982, p. 212): "prior to this time alphaberization had been largely restricted to lists of things which had no known or discernible rational relationship - one alphabetized lapidaries, for instance, because no classification of stones existed." But now certain scholars began to take a text with a clear serial order - the Bible - and re-wrote it in a new order of ease and utility for the reader, or rather with "a tacit recognition of the fact that each user of a work will bring to it his own preconceived rational order alphabetization was not simply a handy new device; it was also the manifestation of a different way of thinking". 2

In sum, by 1300 these scholars have invented

\footnotetext{
' Perhaps most striking of all is the re-writing of the Bible. The traditional unglossed Bible was in two-column format. But around 1150 ( Rouse \& Rouse, 1982, pp. 208-209) the lay-out aiters to one column centre-page flanked by two columns. narrow-spaced, of glosses with key-words underlined and tie-marks linking gloss and text. By 1170 a text of the Psalms has two columns where commentary is distributed within the column around the text (written in larger letters). with the addition at either margin of three more columns of apparatus: of these the inside one has cross-reference within the Psalms, the centre one gives author reference and citations with vertical lines serving as primitive quotations marks to distinguish different authors, and the outside one gives cross-references to other parts of the Bible. Rouse \& Rouse ( 1982 . p. 209) comment on the utility of these devices: "we still use virtually all of them today, save that we have moved the marginalia to the foot of the page".

2 Interestingly, perhaps inevitably, this new ordering began only at the margin of scholarly activity, in the writing of "distinction collections", which gave various figurative meanings of words in the Bible plus a supporting Biblical text and were designed probably first "as the basis for classroom lectures." In the late twelfth century only a few scholars like Peter the Chanter and Alan of Lille (c. 1190$)$ use alphabetical arrangement, and even the innovators do not dream of using the strategy in more mainstream work: they continue "glossing the Gloss in traditional fashion". The extension of the technique comes in the next generation. notably in the creation of the first Bible concordances by the Dominican scholar-preachers in Paris. Alphabetical indexes become well-known by 1250 (for the Bible, the Fathers and even Aristotle) and before 1300 alphabetization is being used all over literate Europe, for "collections of exampla . . a alphabetized by topic, tenant and tax rolls alphabetized by name and so on".
} 
an impersonal kind of text which deploys space and number in a new systematic way. Rouse \& Rouse sum up the innovations under three headings (1979, pp. 27-34):

(1) the use of alphabetical order "as a means of arranging words and ideas",

(2) the development of a new visually oriented layout for book and page, involving rubrics, paragraph marks, different letter sizes, lists of chapters and running headlines and formal cross-references: none of them invented at this point but all brought together in consistent application for the first time, and

(3) the emergence of systems of reference with which to designate portions of text and codex.

Here they make one last observation of importance: "toolmakers were nearly unanimous in their rejection of roman numerals as being too clumsy; . . The interest in . . . referring to materials was significant in hastening the acceptance of arabic numerals in the West ... In the course of the thirteenth century they supersede roman numerals and letters . . f for use in foliation; and the use ... for line-numbering . . . before mid-century is one of the earlier instances of routine, wholesale use." One needs to stress this, since it has been pointed out that Latin official tradition retained roman numerals: the Medici accounts switched completely from the roman only in 1494 , and the Exchequer was still using them in the sixteenth century (Murray, 1978, pp. 169172 ); even the Arte del Cambio in Florence forbade members ( $c .1300$ ) to use arabic numbers, requiring writing to be done openly (aperte) and in full (extense) in letters. But this is not due to ignorance or unfamiliarity. It has to do with a concern with forgery and duplicity at one level and, more generally, it reflects a world whose ways of writing and reading are changing (as we shall note below concerning the audit): the alphanumeric system spreads, but it has to be validated in terms of the tradition which it supplants. During the changeover arabic numerals are only the supplement to the "real" official writing of word and number.

With that proviso, this constitutes our essential first point: that there was a shift to the deployment of a new kind of alphanumeric way of writing going on, but that it was also a more general shift to a new visual ordering and gridding of writing, and that the key intermediaries were pedagogues, concerned primarily with problems of knowledge.

\section{THE RISE OF EXAMINATORIAL POWER: STUDENTS, MASTERS AND GRADUATES}

However the point that follows is that these new knowledge techniques were also ab initio deployed in the service of power. At first this took place principally in the immediate institutional field; the critical "inquisitorial" reading and rewriting of texts was carried on primarily by teachers in the schools of Paris and Bologna, and during the twelfth century it eventuated in a critical inquisition of their students in the first formal examinations in western history. It was a gradual process, existing in neither place in 1150 and in both by 1190 : and it was a doubleedged development. For the student it was an ordeal, carrying the threat of humiliation and failure and the exposure of ignorance and error, but once passed it was the mark of success and status, marked by the new prominence of the title magister.

Examples would include men like Thurkill and such famous names as Thomas à Becket, who began his career, after study at Paris, as a clerkaccountant (clericus et rationalis) in London in the 1140's (Clanchy, 1979, p. 68). Yet perhaps more convincing to alphanumeric eyes is statistically-based observation of the changing definition and increasing influence of the magister (Baldwin, 1982, pp. 151-157; Southern, 1982, pp. 134-135). Southern points out that the title is restricted before 1135 to a specific category, the master in charge of the cathedral school; thereafter it is used much more widely in "a new system of nomenclature . . to specify their status as professional men". Baldwin takes the development a stage further. By the late twelfth century the French king had "at least a dozen" magistri, while at the English court they were "a pervasive presence", in the chancery and as justices: in 
1202 the Pipe Rolls name 22 of them. And as this happens they acquire a new title as magistri officiales, at first a bishop's chief legal officer, later, as the generic term, the "official".

Clanchy $(1975$, p. 682$)$ puts a general question: "Were graduates employed because they had learned specific skills or because their patrons were following fashion?" This is a question we can now answer, by pointing out how educational techniques were appropriated, by those who learned them, as techniques of power. The superimposition of power relations upon knowledge relations becomes clearly visible as the technologies involved - archiving, crossreferencing and examination - are quickly appropriated by the first generations of exexaminees, the Graduates, in a number of new formations of power.

We would briefly mention two: the Inquisition and Purgatory (both uniquely Western Catholic creations ) are inventions of this period: the former adapts the critical reading Abelard's inquisitio - and the new writing techniques of scholarship to the juridical purpose of collecting, collating and, via indexes, cross-referencing depositions about suspected heretics, and then subjects persons to an examinatorial form of trial (where one does not know what questions will be asked and the examiners are also the judges who decide passing and failure); the latter (Goff, 1981 ) sets out categories of sin and punishment and places God in the role of Great Examiner in the Sky. And finally of course there are new systems of accounting. These, whether single-entry or the more complex double-entry, draw on the writing formats of scholarship, but they also function as systematic examinations, both of the written statements of incomings and outgoings and of the honesty of administrators.

\section{THE NEW POWER IN ACCOUNTING}

If we have established a prima facie case for a connection between educational practices and accounting practice, it remains for us to specify the range of ways in which the new forms of accounting developed and the kind of powerknowledge relations which were set in play. There is no straightforward historical exposition possible, since there was no straightforward development in accounting practice. As is well known, forms of single-entry accounting were adopted widely throughout Europe and were not necessarily replaced by double-entry even in large-scale sophisticated financial organizations like the German, Dutch and English banks right into the nineteenth century (Yamey, 1977). At the same time, where double-entry flourished, in the Italian city-states, it was used to an almost dysfunctional extent, e.g. in the keeping of family domestic accounts (Goldthwaite, 1968, p. 24) and the system, once in place, might continue for centuries, regardless of fluctuations in the family fortunes. Therefore the criterion for the use or non-use of double-entry hardly seems to be one of economic rationalism and, in order to try and evaluate the new power in accounting, we intend to hold that criterion in abeyance. Accounting's power was in part an economic power, but, we argue, it will not reduce to such terms.

The new systematic writing, as an aspect of the new textuality, made possible a new kind of control - indeed it appears, as we shall suggest, to have invented the very word. This control (over goods, money and persons) was produced out of the ever-more-sophisticated ways of gridding and re-writing texts and one did not need to invent double-entry to discover this general new power. Thus we shall begin this section with a historical analysis of developments within the field of financial administration which led to the emergence of systematic, though not doubleentry, accounting procedures and to the articulation of a discourse of control, during the twelfth and thirteenth centuries. We can specify the role played by clerks and magistri (a) in administration itself and ( $b$ ) in disseminating the new discourse, either by setting up schools or by writing handbooks on calculation and the ars notaria. (Frequently in fact, the same individuals are involved in more than one way.)

Having done this, we can then proceed to the specific case of double-entry. This, we shall 
argue, can only be understood in the light of changes taking place in the writing of money (e.g. the development of money of account and the bill of exchange). Yet is is still not purely a system of economic rationalism. It constitutes an extreme form of the medieval discourse of control, and as such it is still very different from modern discourses. We suggest that this is because it lacks the modern micro-technologies for control of the individual subject, in particular any means for constructing a mathematical expression of human value such as is embodied in the mark. It cannot produce a discourse of human accountability wherein the individual subject is rendered, as Foucault put it (1977, p. 193 ) as "calculable man". Indeed it paradoxically appears to produce what is in his terms the opposite, an intensified discourse of memorability, constructed directly out of the detailed information afforded by the new style of accounts (Hyde, 1979, pp. $114 \mathrm{ff}$.).

\section{REWRITING FINANCIAL ADMINISTRATION: THE EXCHEQUER, THE DISCOURSE OF CONTROL AND THE AUDIT}

Looking chronologically it would appear that significant changes in the recording of information and the drawing-up of accounts take place in the administrative arena before they occur in the merchant world. The Papal Chancery begins to organize its archive and create new administrative posts (like the Capellani) even before 1100 (Ullman, 1970, p. 327). And a similar process can be traced within the English Exchequer from roughly the same time. For some decades after Thurkill's time (c. 1100) the Exchequer apparently operated with simple forms of calculation and archival recording.

Computation was via the abacus system, using a chequer-board table (hence its name) and recording took place on the so-called "Pipe
Rolls". The format of these needs noting: they were not a long roll on the ancient model, but a series of sheets, called pipes, one for each shire, with entries in no fixed order. Entries are ( $c$. 1130) of the form, the Sheriff "accounts for the profits of the forest of Cirencester. He has paid $40 \mathrm{~s}$. in the treasury and is quit" (Douglas \& Greenway, 1981, p. 611), in other words they are in narrative form, each entry as a kind of paragraph. The sheets were stitched together at the top in ad boc order, which varied from year to year, and then rolled up for storing. Clanchy (1979) points out also that although the Rolls form a series they are not systematically used for subsequent information-retrieval (indeed in the absence of indexing they cannot be). Like the Domesday Book they are one-off snapshots of things as they are (Domésday itself was not consulted as an archive for some 200 years, by which time the new textuality was taking effect on how administrators read documents). As proof of the limitation of the documentary archive Clanchy cites Edward I's quixotic command to "search all the documents" in the Chancery rolls in 1291 to prove his right to the Scottish crown: the archival chests (archae) were in different locations with their contents still unlisted, so the search was "absurd" (p. 261 ).

However, a first level of reorganisation took place in the Exchequer before 1200, as can be seen from that extraordinarily valuable contemporary document, Richard Fitz Nigel's Dialogue of the Exchequer (ed. Johnson, 1983). The earliest system had involved doing calculations on the abacus-table, making up wooden tallies for each transaction, the larger part (or stock) being given as a receipt, the smaller foil (or countertally) being retained, and the whole transaction being recorded in the Pipe Roll. By 1180 , the Dialogue shows, tallies and abacus are being supplemented: calculations are still done by the calculator at the table, but he is flanked by others "sent by the King" (Johnson, 1983, p. 17)

\footnotetext{
"The emergence of "accountability" needs explaining ( see pp. $41-44$ below'). Today the term is used freely both in its specific financial sense and in an extended social one. But we see accountability. even in the financial sense. as being not an immediate and necessary complement of keeping accounts. but instead a historically specific discourse and one sign of a new temporal orientation towards the future that emerges at the beginning of the nineteenth century.
} 
who possibly use the algorism to check him. All processes are doubly performed and checked (the scribe of the Treasury roll has both Treasurer and Justiciar watching him and is seated beside the Chancery roll scribe who is watched by the Chancellor's clerk for every iota). And perhaps most interesting of all, at the fourth bench sits Magister Thomas Brown, who by a recent ordinance has responsibility for a "third Roll" made by an extra scribe who has to sit behind the other two and excerpt what is necessary (quod oportet excipiat) from them, his copy being checked afterwards for accuracy.

We stress this development because Brown's roll was clearly an edited transcript of essentials (it is described later, p. 35, as containing "the laws of the realm and the secrets of the king", and was to be kept by Brown wherever he went ). As such it marks a new level of re-writing the archive and a new power over it: it is in fact a kind of bureaucratic commentary. And be it noted that its author is a Magister: Brown had studied in Italy and then served as confidential secretary for Roger II of Sicily before coming to the English court in 1160 and very possibly bringing this writing innovation with him. It is precisely the kind of power-knowledge connection between the university and the world beyond that the twelfth century is full of (one may similarly note how almost every pope from 1150 on is an ex-student of Bologna).

But the particular interest lies in the legacy of Brown's innovation. His personal roll was discontinued when he left or died (c. 1180), but (a) his scribe may have become the "earliest king's remembrancer" (Clanchy, 1979, p. 47); and (b) in the next generation of English bureaucrats Hubert Walter (who may himself have attended Bologna) introduced as standard practice the making of records in three copies, the third to be kept in the treasury and forming the first archive of "feet of fines" (Clanchy, p. 48).

Out of this new re-writing there emerged a new power-knowledge term, "control". The neologisms contrarotulus and contre-rolle are in use in the English court by 1220 [for citations see Latham (1981) under contrarotulus]. Its coinage is very probably from the Exchequer where the foil was regularly called the contratalea as the Dialogue shows (Johnson, 1983, pp. 17,40 ), so that by analogy with the countertally administrators began to talk of the counterroll, particularly since they already (by 1155) talked of the contrataleator, the keeper of the counter-tallies and in the first mention of the contrarotulus there is simultaneous reference to its keeper as the contrarotulator. This is clearly a familiar mode of administrative discourse. In addition we can be sure that control was an invention of the English state accounts, because they alone in Europe were kept as rotuli (Clanchy, 1979, pp. 105-8), so that the "counterroll" would have been a meaningless construct elsewhere.

In conclusion, then, we can see a first stage in the rewriting of accounts taking place. Brown's roll - perhaps we should call it the first book of control - forms a commentary within a context where a considerable range of re-writings of monetary statements were taking place. This is not yet the internal re-writing of the text which will eventuate in double-entry, but it is an important aspect of the general re-writing which was necessary, and has its own kind of power-knowledge precipitate, in the emergence of the contre-rolle. It also has the effect of disseminating accounting in this form to institutions and persons connected with the court and/or the intellectual elite during the thirteenth century: Clanchy mentions the pipe rolls of the bishop of Winchester which begin in 1208; the records of Christ Church, Canterbury which are the first known in England to calculate a rudimentary form of profit, on the abbey's manors from 1224; the accounts of Merton College, Oxford, dating from 1277; and of individuals like Adam of Stretton who was an Exchequer official in the 1280s and Eleanor de Montfort, Henry III's sister (Clanchy, 1979, pp. 71-72; also Stone, 1962): Eleanor's accounts for 1265 (Clanchy, Plate XI) detail expenditure day by day, by paragraph, with the day's total added up at the end of each paragraph (all numerals are roman ).

More generally the new power-knowledge relations circulating among this social network can be discerned in the development of that dis- 
tinctively new accounting practice, the audit. "Audit" is another neologism, like control, which is absent from ancient Latin and we suggest that it demonstrates strikingly the power which the new examinatorial discourse has to extend itself beyond the confines of the university.

Clanchy remarks (1979, p. 215 ) that the term, though new, reflects the continuing power of the old tradition that real reading was reading aloud: the formal official event of accounting must be done openly before an audience. Thus Abbot Samson of Bury St. Edmunds (c. 1185) "heard" the weekly account of his expenditure: and when the Franciscans arrived in England in 1224 the superior "heard the first annual account" which showed such lavish expenditure that "he threw down all the tallies and rolls and shouted 'I'm caught' and never afterwards wanted to hear an account".

Yet it did not simply reflect the old tradition for it was an aspect of the new silent visual inspection. Samson, so his biographer Jocelin says, inspected his register of rents, the Kalendarium, almost every day "as though he could see therein the image of his own efficiency as in a mirror" (Clanchy, 1979, p.215). Pope Innocent III manifests the same kind of double attitude (ibid.) when (in 1200) considering Gerald of Wales' claims to be bishop-elect of St. David's: at one point he searches a register of bishoprics rubric by rubric, but when later Gerald hands him a transcript of a letter bearing on the case, he hands it to Cardinal Ugolino to read aloud. This reading aloud is, as Clanchy says, "not being done to enable everyone present to learn the contents" since there are only the three of them there. On the other hand, in the light of Saenger's recent research (1982), it is hard to argue that reading was still for this literate elite "primarily oral". We would suggest that oral reading and "auditing" had taken on a new power from the development of the new formal oral examination of the universities. The audit is a product of a new complex world where (a) silent inquisitorial reading can now turn the text into a mirror while at the same time (b) formal oral validation of that reading has been given a new lease on life by the invention of the examination.

The exercise of power relations appears very strikingly in the role of the auditors $v i s-a ̀-v i s$ the preparation of estate accounts from the thirteenth century on (Drew, 1947; Noke, 1981). While the basic information about receipts and payments of money and produce is essentially similar to that kept on estates in Graeco-Roman antiquity (Yamey, 1977, pp. 11-12), a distinctive feature of the medieval development is that the final account comprises not merely the actual transactions but those which the auditors consider should have occurred. They would rewrite the entries in the accounts to reflect, e.g. the "expected" yield of a field or a flock, and thereby surcharge the bailiff or reeve for the additional amounts due to his lord. The audit exercised not only surveillance but a primitive kind of normalising judgment, perhaps a "reg. ularising" judgment (i.e. one which imposed a rule of number). It gave at least the appearance, if not the reality of control (as Drew points out, the "standard" yields and allowances that the auditors would expect must in practice have left the estate officials considerable slack, as otherwise it is impossible to understand how they would have been able to meet the surcharges that were frequently levied - for these were sometimes two or three times the official's annual salary).

\section{THE SOCIAL POWER OF THE IJNIVERSITY ELITE}

Given this overall context it is hardly surprising that some of the principal beneficiaries and" promoters of the new discourse should be the clerks and magistri. Recent work has established just how far this power was disseminated within and around the university world. Clanchy (1975, pp. 685-686) notes that by the mid-thirteenth century "the great majority of clerks and accountants . . . were trained at universities", largely because alongside the traditional liberal arts there had grown up a training in the notarial art as part of the arts dictaminis taught within 
the law faculties. And dictamen teachers were not slow to promote their subject on the basis of its utility: Boncompagno "the greatest dictator at Bologna" claimed his subject "was worthy to be an eighth liberal art" on those grounds, and Clanchy observes that a law and business school in Oxford may date from King John's reign, partly on the evidence of John of Oxford's "Luffield Book" and Walter of Henley's "Treatise on Estate Management" (Oschinsky, 1971).

Judging by the fourteenth century evidence on the activities of Thomas Sampson as a teacher of business methods at Oxford (c. 1350-1400) it would appear that one development was for individuals to set up schools alongside the university curriculum (Richardson, 1941; Orme, 1973 ) as the notarial art became sufficiently complex to be studied in its own right. But that was only part of a more general dissemination of a pedagogic discourse around the field of accountancy: firstly these teachers frequently wrote formularies giving specimen accounts and also "arts" of business, which extended knowledge of the discourse beyond the confines of the university world: and secondly there was increasing scope for independent schools located in main business and administrative centres. Under this heading one can cite the development of the independent Chancery school attached to the English court and of similar independent institutions like the Inns of Court - in England an initiative which really gathers strength during the fifteenth century (Griffiths, 1980, pp. 117-121); or for a leading business city like Florence one can cite the figures of the careful and accounts-minded chronicler Villani, who "in 1345 estimated at 1000-1200 the number of children studying 'abaco' and 'algorismo' in Florence alone" (Murray, 1978, p.172).

\section{THE CONTEXT OF DOUBLE-ENTRY: MONEY AND THE "DOUBLED" (THEN "DOUBLE") SIGN}

The second level of reorganization is that which has traditionally been discussed in his- tories of accounting (e.g. Yamey, 1964; de Roover, 1974): the internal re-writing of the text into double-entry format and the development of an interlocking network of books of account in the merchant and banking world. As we said briefly above, this specific development necessitates some consideration of another aspect of medieval re-writing, the re-writing of money into new forms. We would give two justifications of this: first the historical one that doubleentry is, unlike the other developments we have discussed, quite clearly bound up with new activities in banking and commerce; second we would make a more general point.

Hyde (1979, p. 113) who characterizes these activities, which take place around the middle of the thirteenth century, as "a major breakthrough ... in the use of literacy in the field of long-distance commerce and finance", makes an illuminating analogy with the compass. He divides the new writings involved into two categories, the first being "accurate records of business transacted, through ledgers and journals of varying degrees of sophistication ... these constituted as it were the fixed ley of the compass. The moving leg... was composed of correspondence: letters of differing shades of formality, from bills of exchange to informal notes". But we see double-entry not just as one aspect of the "fixed-leg" writings - it is the culmination of both of the new activities. To understand why it is necessary to go beyond Hyde's admittedly useful analogy and recognise that there is more than just a new literacy: it is a literacy built, in all its aspects, upon a new textual complexity. There is in both the "fixed leg" and the "moving leg" of the new writings a kind of doubling taking place.

Again we would draw upon an aspect of Foucault's work, as developed in The Order of Things (1970): the notion of the "double sign". All the secondary books used in archiving and referencing involve a doubling of signs in his sense (the signs of the Bible are doubled internally in the glosses and externally in the concordances and indexes: in contrarotuli and early ledgers they are doubles of the signs written in original books of entry). And a similar kind of 
doubling takes place in the "moving leg": particularly in the bill of exchange, which manifests a distinctively new double format and which was, as Roover pointed out (1974, p. 185), a "system of bilateral written exchanges", and in money of account, which begins to be written as both debit and credit.

Strangely this notion of the double sign is one that Foucault never applied directly to money, perhaps because in The Order of Things he paid scant attention to this early medieval period. And it needs to be used with care, because his focus was directed so much upon the sixteenth and seventeenth centuries. Indeed a distinction which we would introduce is that in the early period the money-sign is a doubled, not a double, sign. As such it is something different and simpler than the complex money-sign which begins to be written during the sixteenth century. But the latter can only be understood as an evolution (and also a transformation) of the former.

Foucault's double sign is a reflexively involuted combination of signifier and signified: it is the sign as perfect reflexive representation, the "duplicated representation doubled over upon itself" (1970, p. 65). ${ }^{4}$ This analysis can be applied to the writing of money as it exists during this later period. Letters obligatory, promissory notes and bills of exchange, forms of writing which circulate widely from the medieval period, begin to incorporate endorsements and to be traded systematically at discount, at first in the Netherlands and then in England. Neither endorsement nor discounting are practices of the early period, and they both represent modes of turning money instruments into reflexively double signs: endorsement, as the Cambridge Economic History' puts it (Rich \& Wilson, 1977 , Vol. 5, p.326), allows the circulation of instruments to evolve "from transferability to negotiability": second, and subsequent, writing upon the back of an instrument, when guaranteed by legal protection via joint responsibility of all assignees, meant that the paper carried witbin it a new kind of security via control. As multiple endorsement became commonplace the instrument became its own contre-rolle.

In a different but related way discounting turned instruments into double signs: where before writings obligatory and bills of exchange were generally kept by creditors until their due date and occasionally in emergencies presented to the debtor early for encashment with a rebate (rabat) (Rich \& Wilson, Vol. 5, p.330), sixteenth-century Antwerp money-dealers began to buy up unexpired paper at a discount; de Roover (1974, p. 230 ) remarks that after 1600 the London goldsmiths "intruduced the practice of discounting inland bills and later that of putting their notes into circulation", and out of this there came "a new kind of banking based on discount instead of on exchange", found first at a national level in the (private) Bank of England and its paper money.

In this fashion there is a second kind of new re-writing entering into instruments, a mathematized re-writing of value (or writing of double value), for the discounted instrument has both face-value and percentage mark-down. The new "bank notes", with their double value and capability for circulating far and near through an increasing number of exchanges and discounts then develop their own control: de Roover again (p. 231): "After 1715 customers who wished to dispose of their credit by 'drawn notes' were given special paper with a counterfoil or 'check' as a safeguard against frauds. Thus originated the word 'check'." In money terms the endorsed, discounted instrument is Foucault's "duplicated representation doubled over upon itself": it represents a double value via

\footnotetext{
'The extreme example he gives is from the field of art. the perspectival painting to end all perspectival paintings. Velasquez' Las .Heninas: here the painter puts himself. realistically depicted. within the pictorial frame painting a picture (whose back alone we see) of the King and Queen who are reflected in a mirror behind him and who stand outside the picture, on the spot where the painter was in actuality himself standing to paint (and where we also stand to view): author. subjects and reader of the picture are all doubled representations within the overall frame of a picture which is itself a double sign - a represen. tation of representational painting.
} 
discounting and doubles writings of control within and around itself.

Like artistic representation it is in a specific scnse "fictive" writing: both create new worlds, in a sense impossible until they are written, but, once written, real; and the world of paper monies is the precondition for modern national and international economies, where work is done within an economy which turns all relations into money relations and rewards labour, within a nation, in an apparently uniform currency while simultaneously operating across nations with an apparently intertranslatable network of currencies.

Both are similar fictions, for each generates further rewritings which deconstruct the apparent unities: within the visual world trompe l'oeil, non-representational art and the photograph itself as illusion: within the world of value, constant re-writing of instruments into new forms (cheques, stocks, bond issues, credit cards) and the construction of secondary monies (Eurodollars, ECUs, etc.) into a network of multiple forms and monies which works only because it is guaranteed and controlled by other writings, debits, credits and balances within and between varying kinds of banks which are themselves controlled and guaranteed by systems of internal and external accounting.'

We have dealt with this concept of the double sign at some length both because some understanding of it is bound up with the latter part of our argument, but also because we see Foucault's historical argument, set out in The Order of Things, as needing modification. We see his reflexively self-enclosed double sign as being the evolved form of an earlier and simpler "doubled" sign whose history is important in its own right, beginning as it does from within the new textuality of the twelfth century. We stress the point that there is a discontinuity in the history of writing at that moment, and that new ways of writing power-knowledge relations develop out of the discontinuity. Yet the process is never simple nor straightforward. Modes of writing doubled signs only slowly cvolve into modes of double signs, and even then the full power-knowledge implications of this writing are not immediately worked out. It is only around 1800 that this occurs, when all aspects of human activity to do with words, things and values are made subject to technologies of writing - specifically alphanumeric writing. (We shall call this the "grammatocentric" moment, as evidenced for example in the shift to modern examination, where all must write and are then written about, in reports and systems of mathematical grading, and equally in systems of total accountability.)

\section{MONEY, BANKING AND THE BILL OF EXCHANGE}

With this background we feel better able to discuss the internal development of double. entry accounting, for it is perhaps one of the first places, if not the first, where doubled signs turn

\footnotetext{
"We use the terms "guarantee" and "control" acknowledging that these writings, like all others, are never perfect and absolute: the history of money-as-writing, like the history of writing itself, is one of constant error, deception and dissimulation; writing creates error and dissimulation even as it produces truth, and as the complexity of writing changes so do these other complexities. Foucault's point was that the discourses of the double sign, in producing a new reflexively self-enclosed kind of writing, produced an illusion of fixity, of the writing to end writing: in the visual field the Perfect Representation, and in the fieid of value that discourse which he named as the Analysis of Wealth. which found in the Earth's supply of gold or land an ultimate fixed guarantee of Total Wealth. But in each case re-writing deconstructed the illusion. and new discourses developed which acknowledged an essential temporality, both in the world and in writing itself. Art rejected the Perfect Representation as itself being an illusion. and the Analysis of Wealth gave way to Political Economy (or Economics) where. after Adam Smith, the problem of value was posed as an essentially temporal one, since, in the new kind of analyses which he helped to initiate, value was created not out of land or gold but labour. In each case (and there are other examples, such as linguis(ics) the illusion of a writing to end writing deconstructs itself into an endless proliferation of further and increasingly complex re-writings
} 
into double signs. ${ }^{6}$ As a power-knowledge development it has, as we suggested above, two aspects: the development of systematically organized recording techniques (Hyde's "fixed leg") and the incorporation into the archival record of a new doubled form of money-writing. At its heart lies the object of its writing, the new kind of money which was beginning to circulate from the twelfth century on, which was not yet "double-sign" money but was a distinctively new development in the history of the writing of money.

One aspect of this is the appearance of the fractional reserve and fiduciary money, which was not a feature of ancient deposit banking (Finley, 1985, pp.141, 196-198) nor apparently of earlier Islamic finance (Udovitch, 1979). From late twelfth century notarial records (de Roover, 1948, p. 247) it appears that Genoese moneychangers were using money deposited for reinvestment while "the depositors neither gave their formal consent nor even knew what was going on", i.e. they had as yet no formal counter-roll: this meant they would not necessarily receive back the actual coin deposited so that deposits "became transferable claims to a given sum of money", and money itself became fiduciary money: not only that, but within the books of the moneychanger it became simultaneously written as debit and credit, i.e. a kind of doubled sign, and what was due to various depositors might not at any prior moment be available except as a written entry in the books - a de facto fractional reserve. The shift was hesitant: by 1200 (de Roover, 1974, p. 202) "depositors were granted credit by being allowed to overdraw their accounts" and merchants used their accounts "to make payments by transfer", but it appears that transfers were made in person by the merchant or a known intermediary, i.e. the writing itself was not yet its own guarantee.

Similarly with the most famous medieval innovation, the bill of exchange: it was, as de Roover says, "a distinctively new instrument" providing the form of a new system of bilateral written exchanges. In its early "pure" form it involved (de Roover, 1974, p. 185) "two payments and four persons": ( 1 ) a "deliverer" bought a bill for cash from (2) a taker who drew on a correspondent/agent abroad: at the due date the agent (3) paid a given amount in local currency to (4) the payee to whom the original bill was made out who was usually an agent of (1). But variations were quickly possible: two of the four parties might well be (de Roover, 1974, p. 211) "merged in the same individual"; the deliverer might also be the payee or even the taker "when a merchant having a debtor and a creditor in another city drew a bill on his debtor to pay his creditor". And it produced its own forms of dissimulation as in "dry exchange" which was a spurious exchange transaction in order to give a straight loan in one place - de Roover's example is of bills drawn on the Medici banks in Venice and Bruges in order to give a loan in the former (1974, p. 195).

De Roover however tends to anachronism, seeing the practice as really being a form of discounting, concealed because of the Church's prohibition on usary. So he says (e.g. 1974, p.332) "discounting ... was ... ruled out, but the bankers cleverly shifted to exchange dealings as the basis of their operations". What this obscures is that compared to discounting exchange bills are a fundamentally different, because simpler, form of the double writing of money. It is a difference he cannot altogether ignore; it surfaces for instance where he says (1974, p.242) "an exchange transaction, in order to be complete, always involved two bills instead of one": there was, in other words, double writing but on two papers operative in different places at different times. The writing of value had not yet been collapsed into a double writing on one paper.

The fundamental difference is well illustrated by Alfonse Leone (1983), who has accordingly worked out the ramifications of a system which knew no other writing of money than the bilat-

\footnotetext{
"If it is the first, perhaps this is because it is a discourse, like the distinction collections (see footnote 2 ) on the margin of scholarly activity:
} 
eral transaction. He suggests that one cannot understand the system in terms of profit on an individual transaction: because of the shifting exchange rates profit and loss were "variable and uncertain cost factors" on any given transaction (p. 623). The system depended first upon a "massive network of correspondents" (p. 620), often bankers themselves, operating a series of correspondence accounts, charging a "provision" rate for each bilateral exchange and then directing and redirecting bills to various other correspondents in centres with the most predictably favourable exchange rate: so "Florence instructs Naples to settle the account with Palmero while Avignon in turn repays Naples . . . (since) exchange between Naples and Palmero was very much in Naples' favour whereas that between Avignon and Naples was to the advantage of Avignon" (p. 623).

Again as with dry exchange the transfers became fictional in the sense of having no existence except as writing, as when "a remittance draft was made out on a third market ... which was not the place of residence of either the beneficiary or the drawee" (p. 624). But the underlying point is that, no matter how sophisticated the transactions, they always remained doubled writings, bilateral in form. The system functioned as a constantly multidirectional network of bilateral exchanges, supported by further bills, for instance "the so-called 'bills of advice' providing ... information on ... changes in exchange rates, but also others bearing orders for remittances or drafts on other piazze" ( $p$. 622 ), with the whole process re-written into the network of "correspondence accounts" which registered all debit/credit transactions and over time reduced cash transfers to a minimum since the multiple bilateral operations between agencies "could be regulated by very small settlements". Such a system could not, because of the inherent limitation in its doubled written instruments, have as its object "profit" in the modern sense: "the primary objective ... was the international mobilization of money and credits" ( $p$. 623 ) along the most predictably safe lines.

\section{THE POWER OF THE NEW TEXTUALITY AND THE DEVELOPMENT OF DOUBLE-ENTRY BOOK-KEEPING}

Money was developing, then, as a historically new kind of doubled writing, both as debit/credit and in the bilateral system of transactions. Such a system had its limitations (which would only be overcome when money began to become a double sign ), but it also made possible a new kind of re-writing of money in accountbooks. Clearly that process was taken farthest by those who dealt most fully with the sophisticated money instruments, and it may even be fair to say that given the nature of the new money the movement towards double-entry was inevitable, just as it was impossible before. But that can only be said so long as the writing of money is seen as one aspect of the new textuality, and one expression of the new power-knowledge relations.

So if we turn to the internal development of the lay-out of business accounts as described by de Roover (1974, pp. $121 \mathrm{ff}$ ), the earliest record to survive (from 1157) is "a few figures jotted down on three scraps of paper in the cartulary of the Genoese notary, Giovanni Scriba", i.e. a simple chronological and unsystematised written reminder. By 1221 a Florentine account-book, written in the vernacular, has loans entered in paragraph-format with space for noting repayments as they happened "in chronological order without any separation other than a punctuation mark" and when space was inadequate "the book-keeper was forced to crowd in additional entries as best he could" ( p. 122). It was, as de Roover says, a "clumsy arrangement", but already it shows an adoption of the simplest new textual techniques, paragraphing, punctuation and indeed the adoption of a separate secondary book for re-writing transactions. Qua text it is still basically a chronological narrative but its nascent systematization of repayments under the relevant paragraph with separation by punctuation offers a measure of visual control, and subsequent reorganization of the paragraph takes this further by adopting further scholarly techniques. 
De Roover cites the Fini account-book ( $c$. 1300) which, while still kept in paragraph form, contains "accounts for operating results and expenses as well as the usual personal accounts for receivables and payables" (p. 123) but which also gives for each entry "a cross-reference to a corresponding debit or credit". De Roover cau. tions that there is "no indication regarding the procedure used in closing the books. At the end do we have a real balance... ?"Very possibly not, for it seems to us that the notion of striking the balance is an epiphenomenon, the result made possible at the end of this movement towards rewriting these books as books of doubled signs. We think it significant that the term "bilancio" is not found until the fifteenth century, first in the Florentine catasto's tax records in 1427 "in the sense of any financial statement whether or not it was a real balance", and then in 1446 at the London branch of the Medici bank (and so presumably throughout the Medici system) in the sense of a true balance (de Roover, 1974, p. 156, n. 4).

At this earliest stage people are groping tuwards formats which give increasing control over the new kind of money in which they conduct their business: so they are concerned to rewrite chronological entries into various artificial orders. In the Farolfi ledger of account for operating results (c. 1300) again all entries have cross-references to corresponding debits and credits, and the text has been further gridded by placing amounts (still in roman numerals) "in extension columns instead of . . . in the narrative" (de Roover, 1974, p.124), thus facilitating a separate arithmetical calculation which can relate to entries in other books (de Roover cites a separate libro dell' entrata e dell' uscita and a libro rosso for merchandise accounts). A cashbook from a Sienese company, probably the Salimbeni ( c. 1280) forms part of a quite sophisticated artificial ordering system: internally the text is divided with receipts in the front and expenditures in the rear and a cash balance was computed weekly, while the text itself is only one part of a system of some six other books including a debtor/creditor book, sales book, foreign exchange book, etc. It is possible, de
Roover argues, that some of these texts (which are all from Tuscany ) represent a kind of doubleentry, because of the cross-referencing system (which suggests that it is not the format as such, but the organising principle which treats money of account as a kind of doubled sign which matters).

However, another kind of re-organization was developing in North Italy, the bilateral lay-out or tabular form (de Roover, 1974, p. 136). Again it is not clear that this was double-entry at first: in fact it appears that though "the Genoese bankers were using the tabular form in 1313" the accounts were still single-entry, albeit that by 1340 the accounts of the stewards of the Genoese Commune had taken that final step. In any event, one can conciude that, where in 1250 accounts had begun only halting steps along the textual trail blazed in the scholarly field, by 1350 they had developed so far that they constituted what has generally been seen as an independent sui generis kind of new text developed by and for merchants.

We hope that it is now clear that this development had very different origins. The fullydeveloped double-entry system, with bilateral lay-out and systematic cross-referencing of debit and credit is a particular form of the new general textuality. The thirteenth century saw the development of a new metaphor for the book, the book as Mirror (as expressed in the title of Vincent of Beauvais' encyclopaedic work, the Speculum Maius, which was made up of subsidiary mirrors, the Speculum Naturale, the Historicale and the Doctrinale). Double-entry is perhaps the finest expression of this metaphor: it was a mirror-book embodying the balanced and interconnected writing of the equal and opposite signs of debit and credit - or rather, like Vincent's Speculum, it was an interconnected series of such books. And in achieving this new discourse it underwent the same conversion as the scholarly discourse: from being a narrative it became a commentary, a writing which meticulously followed the chronological narrative while re-writing it in a new non-chonological and impersonal format which produced both new knowledge and new power - a paradox of 
doubling, for, as Foucault once put it (1981, p. 58): "commentary must say for the first time what had, nonetheless, already been said, and must tirelessly repeat what had, however, never been said."

And at the same time, it became not just any commentary but, again following the powerknowledge steps taken in the university, an inquisitorial or examinatorial commentary of a quite new scope. The modern scholars are agreed that its primary function was not balancing the books per se, but in affording a new measure of control: control over the flow of goods, over excessive monetary outgoings, and over subordinates, particularly the last. The new accounts could be examined simultaneously for internal coherence and external validity. The more rudimentary the account the less the potential information and control. The chargedischarge system used in fourteenth century England and later is rudimentary indeed, but nevertheless within its limitations performs the examinatorial function (Yamey, 1977, p. 12). It arrays arrears, rents and receipts on the charge side against expenses and money dispatched on the discharge and so enables [ through the audit, as discussed above (pp. 22-24)] surveillance over factors. Full double-entry meanwhile could, through examination, re-write itself into increasingly meticulous new kinds of control; as de Roover points out (1974, p. 123), Italian merchants "had begun by 1400 to use accounting as a tool of management and control ... by developing the rudiments of cost accounting, by introducing reserves and other modes of adjustment, such as accruals and deferred items, and by giving attention to the audit of balance sheets."

Yet, as we remarked above (p. 113), even in its most sophisticated form this technology of financial examinatorial control never achieved an accountability of the human subject. It does not construct "calculable man". It seems to be used instead as a kind of perfect Representation of one's financial state, and therefore by extension of one's self. Hyde remarks of the extraordinarily extensive Datini archive (comprising some 574 complete account books and a total of 152,648 extant letters) that, while Datini was probably "unusually fanatical in his attachment to written records ... the care with which the archive was preserved suggests that Datini regarded it in a special way as his personal memorial" (1979, p. 115). Goldthwaite similarly concedes (1968, p. 24) that Florentine accounts give a very "complete picture", yet "in the administration of private wealth, especially con sidering the minute detail found in these books and the modest size of some of the fortunes, its practical value is not so apparent".

However, one kind of practical value, as Hyde then demonstrates (1979, pp. 116-121), was its use for the purposes of memorability. Out of the books of family memoranda there grew a new literary discourse, the lay autobiography and the detailed family history, which exhibit a degree of accuracy and reasonableness, unusual in comparison with other literary discourses of the time, which follows directly from the textual accuracy constructed in the account-books and other family archives.'

As a conclusion to this section, and to underline the intimate relation between the pedagogic world and the new discourse of accounting, we would briefly like to reconsider the work most often cited in discussions of double-entry, Fra Luca Pacioli's Summa de Arithemetica, Geomet-

\footnotetext{
Hyde gives an early example, a "skeletal curriculum vitce" with later additional family details written in the notebook of Guido Filippi dell'Antella around 1300 ( p. 117 ); then there is the "enornously claborated" Cronica Domestica of Donato Velluti ( $1367-1370)$, which is a full-scale literary oeuvre, after which ricordanze books became a recognized literary form around 1400 , and continued "in an undistinguished way down to the sixteenth century and beyond" (p. 118). The most notable of them, however, like Giovanni Morelli s Ricordi (c. 1400) show the author (p. 120 ) "wrestling with his conscience and pouring out his feelings of resentment, guilt and self-pity", i.e. they allow a quite remarkable "expression of self-consciousness which does not meekly follow established patterns" (p. 120); and at the same time they function as empirically-based justifications of what the author and his family had done. As Hyde finally concludes, it is striking that writers "do not, on the whole, weave fantastic claims . . but . . concentrate on surviving documents from which they make reasonable and sober conclusions" (p. 127)
} 
rica, Proportioni et Proportionalita of 1494. It is now accepted that Pacioli functioned as a publiciser of an already-established system: in fact (Eisenstein, 1979) he probably derived his account of double-entry from an early Venetian treatise. But the key point is that Pacioli was a religious pedagogue - friar, doctor of divinity and university teacher. And his Summa is essentially an expression of the inter-relation between the various alphanumeric discourses which had developed over the prior centuries. He writes in the vernacular and employs arabic numerals: he had studied under the painter Piero della Francesca and translated his work on perspective into the vernacular: he had taken his obsession with the doubling of the sign down into the form of the alphabet itself, where he was one of the first to pursue the geometrically "perfect" design of letter-forms. The work was then frequently excerpted for practical purposes, as Eisenstein says, "in countless sixteenth century works, including mathematics texts used in college courses", yet, as she then remarks, "less often noted is the way (it) linked double-entry book-keeping and business arithmetic with Pythagorean harmonies and the music of the spheres". The point is that in doing this Pacioli's work was not an aberration, but rather an extreme expression of interrelations that had always been present between the various discourses of the doubled sign: and it is fitting, even predictable, that he should be a professor and cleric, not a businessman.

\section{THE DELAYED IMPLEMENTATION OF ACCOUNTING TECHNOLOGY}

It has long been known that by the fifteenth century accounting techniques that are recognizably modern were available; the problem has always been to explain why double-entry made so little headway and why the discourse of accounting had such a limited impact on financial and commercial procedures. Again we would suggest that this is not purely a financial or economic problem and that, although certain techniques were in place, there was no power- knowledge framework within which they could discover their modern application. Assuredly certain kinds of power-knowledge relations did ensue from medieval accounting, both within the financial world and more widely. However what was lacking was the kind of disciplinary micro-technology which could produce the modern discursive obsessions with two nowfamiliar constructs: accountability and profitability.

The absence of these two constructs, and their subsequent emergence, can, we suggest, be explicated along two related lines. First there is the issue of the temporal orientation of the whole process of accounting. Accounting was not systematically concerned with the future; it faced the past insofar as it was a record of what had happened and what workers and factors did or did not do and it faced the present insofar as it produced (more or less) constantly updated statements of debits, credits and the disposition of goods. This orientation made a real difference in the meaning of all accounts - both in how they were written and read. There is ample evidence (de Roover, 1974; Yamey, 1977) that ledgers and balances were kept sporadically and that years might pass without a balance being struck even in large eighteenth century enterprises, i.e. they were not written for the purpose of constant accountability. And this pre-modern orientation is perhaps epitomized by the highest aspiration of the accounting handbooks, striking the balance. The spatial lay-out produces (or is read as) a frozen statement of a historic "now": the figures make present what has transpired between a given past and a given present, at their best in a fully interrelated cross-referencing network of double signs, where each action and reaction is recorded in double form and everything "balances".

In short the books exercise a certain kind of control over money, goods and workers, a control which conserves loss rather than aiming to maximise gain. The future is controlled only insofar as the existence of accounts acts as a constraint on those who would cheat - either to be honest or to dissimulate successfully. And this general orientation is underlined by the way in 
which accounts were used, as in Florence, to produce a literary discourse of memorability. Calculability, i.e. the use of the accounting record as a means for predictive control, whether of money, goods or workers, simply appears to be absent.

As regards the control of money per se, this point has been made before. For instance Yamey ( 1977 , pp. 15 ff.) put it this way, that early double-entry "differed in many respects from current practice", specifying the change as being "when profit calculation came to dominate" so that "what had often been incidental became central."

Leone's (1983) analysis suggests that in the early period profit calculation bad to be incidental, and we would take that further by suggesting that only when money instruments becamc reflexive double signs did the question of profit take on a new significance. Certainly in the early period profit can be and is calculated, because that is one datum which the figures yield, but it remains incidental.

However, there is, as we see it, a second reason for the lack of a discourse concerned with accountability and profitability - the absence of a full disciplinary technology which could be brought to bear on (and so create) an analysis of both financial and human value, i.e. which could render the interrelated but separable values of products and persons calculable. Within the economic field of activity, the historical record suggests that this remains the case throughout the eighteenth century with respect to the organization of both financial and behavioural control. ${ }^{8}$

With respect to the former, there is little evidence of a concern with profitability, even though money has begun to be written as a reflexive double sign and profit and loss is fore- grounded [even a major economic entity like the East India Company uses accounting practices that give only limited attention to annual profit measurement (Yamey, 1977, pp. 21, 26 and nn. $56,60,66$ and 70)]. With respect to the latter, we would argue as follows: historians have recently rediscovered enterprises which introduced various disciplinary techniques in order to organize time and space and to prescribe and control work practices, e.g. the Crowley Iron Works (c. 1710), and later in the century Boulton and Watt's manufactory and the Wedgwood Pottery (McKendrick, 1961: Pollard, 1965: Thompson, 1967). Managerial intermediaries are employed and accounting strategies from various traditions deployed - estate management, the merchant companies and the longstanding putting-out system of manufacture (Pollard, 1965, ch. 6). But no integrated management structure takes shape, or as Pollard remarks (p. 250) even "a management science or at least a management technology", let alone a "managerial class". Similarly the workforce has yet to become a "working class" (Thompson. 1967).

The ultimate disciplinary use of accounting can be found (McKendrick, 1961; Hopwood. forthcoming) in Wedgwood's attempts to reconcile his overall expenses with cost per article, which led him to construct a form of cost accounting. Yet even this did not lead automatically to the deployment of accounting in the service of profitability and calculability. Wedgwood's initiative remained a one-off (cost accounting remained to be "rediscovered" a century later) and even within his own factory it is not clear that the innovation led to any sustained efficiency and productivity from the workforce. Its main value lay in the identification and removal of the most corrupt factors,

\footnotetext{
"The history of the word "accountability" supports this view. From the Oxford English Dictionary we find that accounts ren. der agents "accountable" (as an adjective dating to the sixteenth century or before) and even produce "accountableness" ( a seventeenth century noun-form which represents the "quality of being accountable"). However the first citations of the word "accountability" date from 1794 and 1808 . The word is absent from Johnson's 175 - dictionary but present in Webster's 1828 American Dictionary, where it is defined as "the state of being liable to answer for one's conduct". This accountability the extended temporal state of constant liability - is, we suggest, a new word for a new power, summed up in Webster's sole citation of its use: "the awful idea of accountability"
} 
while it also had a certain preventative role in limiting the recurrence of the worst offences.

This may seem to undervalue the significance of Wedgwood's achievement. His organizational system demonstrates to a very high degree what we would describe as a "grammatocentric" structure, where all aspects of what should be, and is, done are turned into writing: there was a detailed code of rules for behaviour, a throughput production system, a "clocking-in" system with tickets deposited in a box, in addition to a constant flow of written reports upon which the cost accounting process was based (McKendrick, 1961, pp. 31 ff., esp. 41-46). Yet there was still no micro-technology for producing the calculable subject, the worker (or manager) who is evaluated as a person and who can therefore internalize a self-discipline based on self-evaluation. Before accounting could acquire its modern power, we suggest, a new technological development, again in the educational field, was needed which would activate a discourse of accountability in both the social and financial arenas.

\section{THE POWER OF "BOOK-KEFPING" IN EDUCATIONAL PRACTICE}

In turning again to the educational field we focus on two features: first on the way in which pre-modern accounting had fed back into a "book-keeping" on pupils; and second on the way in which the development of the mark transformed first education's, and thereby, we suggest, accounting's power.

Accounting had a marked influence on pedagogic practice from at least the sixteenth century, extending the discourse of control by creating a new human book-keeping used on pupils. Yet there was still no technology for creating a measure of human "profit-and-loss" and thus, as we have argued, no discourse of accountability. Yet it is important in its own right: first because it predates the implementation of a similar human book-keeping in the work-place (thus emphasising once again the overlay of education upon labour practices ); and second because it is out of this interrelation between accounting and education that the new micro-technology of calculability, the mark, ultimately emerges.

Control (derived largely from human bookkeeping) was a central feature of the Jesuit Ratio Studionum which was a distillation of current educational practices published in the late six. teenth century. Teachers operated as guards and spies, opening letters and submitting regular reports on bad behaviour and maintaining registers for attendance and conduct; they were aided by pupils who were appointed as officermonitors and organized in a hierarchical system with titles derived from Roman military and political practice (Durkheim, 1977, pp. 245 ff.). Judgement was exercised through punishment for the bad and prizes for the good, based on the evidence of the reports and registers. But this was not a normalizing judgement. Instead there was a system of constant competition between pupils based upon the principle of emulation. Such a system worked well for the very good (and presumably the very bad) but it could not provide a measure of individual profit-and-loss across the total population since it was an ordi. nal system, which gave a measure only of relative worth. Pupils were moved up and down in rank according to performance but there was no independent "objective" measure of self-worth, i.e. it was not a system of marks.

The Christian Brothers a century later utilized similar accounting systems at the elementary level of schooling as their Conduct of the Schools (de la Salle, 1935) shows. It stipulates three kinds of register: a register of class or grade sections, which was an attendance register; a register of promotions, which charted the upward progress (or lack of it ) of each pupil; and a pocket register, whose purpose is not elaborated but presumably was analogous to a waste. book or journal. But again this was not yet a system of individual accountability, for there is still no system of mathematical marks.

In this respect Foucault is fundamentally misleading, for he suggests (1977, pp. 180-181) that these Christian Brothers introduce a meritdemerit system for behaviour, wherein a crime 
worth say six demerits may be offset by a virtuous act worth ten. But the Conduct makes it clear that this is not the case. Crimes are punished (de la Salle, 1935, p. 165 ff.) by reprimands, penances, the ferule, the rod and finally expulsion. Rewards consist of books and pictures. Foucault in fact quotes from a post1800 revision of the Conduct, when the meritdemerit system is instituted, by which time what he calls a "penal accountancy" (1977, p. 180) has come into effect not only in these schools but elsewhere; but in the initial Conduct rewards and punishments still constitute two separate systems. Therefore there is regulation and control, but not yet a field of good and bad marks, i.e. pace Foucault, no "perpetual penality of individuals themselves, of their nature, their potentialities, their level or their value"; there is no discipline which "judges individuals in truth" (Foucault, 1977, p. 181).

The culmination of the pre-modern educational discipline comes in the early monitorial systems of Andrew Bell and Joseph Lancaster (1790-1800) (Salmon, 1935). There was a division of pedagogic labour via relays which used pupils as teachers and monitors, under overall control of the Master, and there was a system of constant emulation of the pupil-teacher by the other students, a system where "bad" pupilteachers were made to exchange places with "good" or "better" pupils and where prizes and honours were awarded to the "best". In addition there was a written structure of control expressed in a set of detailed rules and regulations covering (supposedly) all aspects of behaviour, plus a timetable, plus a set of registers. Within this structure there was a constant recording and exchange of information which enforced control over both pupils and teachers (Salmon, 1935 , pp. 34-44.), but which had not yet achieved the full accountability the mark was to bring. $^{9}$

\section{THE EXAMINATION MARK}

The mark is a construct, like examination itself, which seems so self-evident once invented that its prior absence is perplexing. What we would suggest is that its invention marks a kind of culmination and new beginning, for it brings together technologies that were already present in the use of writing for the purpose of control and for the construction of value, and crystallizes them into a new micro-technology of knowledge and power. It has a kind of double genesis: first as an aspect of the history of examination, it appears at the point at which examinations begin to be written. In considering why the Jesuits, and indeed the medieval universities before them did not have marks, one must note that their examinations were always oral. The mark, historically, appears alongside the written

\footnotetext{
"Bell, for instance, had the Master keep a Register of daily offences (the Black Book), in which not only sins of commission by pupils were entered but any omissions by monitors or teachers which pupils might report. Yet punishments were decided weekly by a jury of boys and the Book thereupon "expurgated" (Salmon, 1935, p. 58). So surveillance was reciprocal but judgement did not normalize. Similarly teachers, monitors and pupils all respectively had to keep a "Register of Daily Tasks" noting the number of lessons said, pages gone over and tasks performed. These were tabulated weekly by teacher and Master and compared with prior performance (Salmon, 1935, p. 75). Again there was a mutual check on teachers and pupils and a means of comparing relative pupil performance. But this was still a recording and judging of acts.

Lancaster's system operated in similar fashion, but without a Black Book; in its place he had a more extensive system of rewards and punishments and more frequent testing. This was still for the most part ordinal, as pupils werc sat in division and moved up and down rank by rank according to each question being answered better or worse than by their neighbour. There was also a category of "merit pupils" who were singled out by a medal worn round the neck and, finally, an interesting quasifinancial system of differentiated reward. Good copybook work was evaluated and rewarded with paper tickets numbered 1-5; three number ones (but not less) would receive a prize worth $1 / 2 \mathrm{~d}$., eight number threes received a prize worth $2 \mathrm{~d}$. and twelve number fives were worth $6 \mathrm{~d}$. (Salmon, 1935, pp. 36-42). This was a sophisticated strategy for inducing motivation through self interest and delayed gratification (still much favoured by fun-fairs and behavioural psychologists). However it was still not a "pure" currency which automatically evaluated all pupils, forming in itself a system of punishment/reward. i.e. there was not yet an extended temporal state of accountability.
} 
examination. Yet this does not appear to be a sufficient explanation.

It is possible to show, e.g. at Cambridge, that the use of marks is introduced for the mathematical Tripos examination in 1792 , some thirty or forty years after written answers had hegun to be required of candidates (Hoskin, 1979, pp. 143144). Yet this early history is shadowy. There is other evidence showing that Ezra Stiles experimented with marks at Yale in 1786-1787 (Morgan, 1962, pp.400-403), but discontinued the experiment in the face of student opposition (including a riot). In France the Ecole Polytechnique adopted a marking system under Napolean's reforms of 1805 , though again whether there was some earlier precedent in military academies like the ęngineering school at Mezières is unclear (Artz, 1964, p. 99). In both these cases marks were given for oral examination - therefore there is no straightforward relation between examinations becoming written and marks being introduced. There is not even any sense of creating something new and significant. Such developments as there were were small-scale and undertaken, as at Cambridge, with no sense of any general implications for the future but ad hoc for immediate purposes internal to the institution. (The felt insignificance of the change is why, as yet, it remains so largely hidden from history.)

The second aspect worth noting in the genesis of the mark is that a new kind of mathematization was taking place on a number of fronts, which was tending to articulate the principle that human qualities could be quantified. Up to a point, ranking, despite its limitations, was a move in this direction, and there was, of course, the extension in the use made of money as the measure of human labour-value from the seventeenth century on. In addition it has recently heen noted that in 1692 Christian Thomasius, a professor at Leipzig and later at Hallé, published a primitive form of psychological rating scale (McReynolds \& Ludwig, 1984); however this was still an essentially ordinal ranking of four assumedly self-evident qualities with no uniform base-line. One might also add that a man like Stiles was especially likely to become involved in this kind of mathematical experiment since he was one of the eighteenth century's mathematical obsessives, in a period when, as Patricia Cohen has pointed out (Cohen, 1983), the modern mathematical obsession which is now taken as the great distinguishing features of American culture was conspicuous by its absence.

Perhaps the invention of the mark is perplexing precisely because it is not just a mathematical innovation and is not a fundamentally necessary aspect of the examination process, and yet, once invented, can so easily be taken to be the one or the other (or both). We see its invention as a crystallization of prior power-knowledge technologies, because only a mathematical marking system is simultaneously a record of accounting of acts and a currency which attributes a differential value to those acts. As such it is a quintessentially double sign of human accountability and profitability. Its genesis can be understood as a kind of ultimate development in the historical process of double writing set in motion in the medieval period. It is not just a number but a specific kind of expression of human value, a double sign of human debit and credit - in other words a supramonetary money of account, according a supra-monetary value to human performance and product which is then entered in ledgers to provide both overall statements and individual balances. Its invention, as we see it, marks the most significant locus of intersection between accounting and education practice to the point where it transforms the latter's power-knowledge possibilities, activating the micro-technology which produces, positively and insistently, accountability and profitability. Subsequently, in a process analogous to the medieval one, those principles are disseminated out again into the field of economic and financial practice.

\section{THE OLD VS THE NEW: BENTHAM'S BOOK-KEEPING}

The mark differs from ordinal ranking in being "grammatocentric". Ordinal ranking has a physical correlate: A stands above $B$ who stands above 
$\mathrm{C}$; and it has no means of objectively measuring gaps between A, B and C. Marks move away from physical correlation by existing purely as writing, and, as writing, produce the measure of objective worth - a worth which constructs a new double value which cannot be written before, the specific value allocated to each student's performance and a general standard of value written across the population (one early such standard is the "Class" of degree at Cambridge, more generally there develop "norms" of performance). The mark is grammatocentric because it is an apparently pure and self-contained written sign of value, an unsullied currency whose monetary dimension is erased as its financial pre-history is overlaid in its apparently independent development within educational practice. That apparent purity should, we suggest, be regarded with all due suspicion: and at the same time the significance of the mark in transforming pre-modern systems of human organization into disciplinary systems operating on calculable subjects should be given its full weight.

We suggested above that the Wedgwood system of work organization remained pre-modern precisely because it had no technology for turning its workforce into a population of calculable subjects. We would apply the same argument to the most extreme attempt, within the educational field, to apply the discourse of accounting without incorporating the microtechnology of the mark. Jeremy Bentham's Chrestomatbia (1816) outlines a plan for an advanced total schooling based on monitorial principles; it demonstrates clearly how far that premodern pedagogy could be taken and yet fail to be disciplinary (it is perhaps symptomatic of that failure that the work should, like his Panopticon, be so little remembered until recently).

The advanced stage which Bentham, along with his brother Samuel, had reached vis-à-vis accounting has been noted by Hume (1970). He had the modern temporal orientation of concern with "comparative profitability of the different courses of action open" (Hume, p. 22) and "stressed that bookkeeping must serve the dual purpose of control ... and decision making and that it could do this only by providing a complete and analytical account of the enterprise's use of resources" which required that (p. 24) "the accounts must disclose all mistakes and all misconduct occurring within the institution": everything was to be turned into writing and re writing, in two kinds of books, the elementary and mainly chronological books of entry and the secondary aggregate and methodical books, and beyond these the tabulation of information in forms "facilitating comparison and choice" ( $p$. 30). Past and future, managers and workforce are all to become subject to an accounting eye, in what is one more expression of his Panopticon priciple.

The Chrestomathia incorporates this commitment to accounting: indeed Bentham's perception of the scope of accounting is particularly remarkable, since he explicitly sees it as coextensive with reality: financial book-keeping, he says in his commentary (Table 1, section 90), is "but a branch of an art of the most extensive range and proportionable importance: viz. the art of Book-keeping at large; the art of Registration and Recordation; the art of securing and perpetuating Evidence" and allowing the Master "to see without being seen". In one sense this is a startling reversal of accounting's specific history since it erases the financial dimension; in another Bentham is the first to articulate clearly the power-knowledge relations which had always been present in the more general history of which accounting is a part. Yet at the same time his discourse remains pre-modern, limited by the absence of the mark. ${ }^{10}$

The disciplinary intention is manifest and there is a new explicit grasp of the power-knowledge possibilities of accounting but equally

\footnotetext{
"1" Everything else is in place: there is an Aggregate Register detailing each pupil by name and absences, but then, in place of marks, pupils are rendered calculable by their ordinal "rank from the last place-capturing contest". Out of this is produced. for the total population, a Comparative Proficiency Register, detailing class, exercises done, lessons said and cumulative rank. and at the individual level each student's "account is formed by copying from the Aggregate Register and summing up the
} 
there is no currency which can finally create a system of total human accountability. Bentham is to be located within that general change which we describe as "grammatocentric" but the point of his failure suggests that such a change is not simply to be associated with any one person in any one place. The new system, whether one calls- it "disciplinary power" or "grammatocentrism", develops out of various experiments in the writing of surveillance, judgement and examination. And as with the medieval transformation in the writing of power-knowledge relations, it only gradually comes to realize its implications.

\section{HUMAN ACCOUNTABILITY}

With the invention of the academic mark and its behavioural counterpart, the merit-demerit system, the textual structure of registers and records could be activated as a discourse of human accountability. In this discourse new concerns get voiced and become part of takenfor-granted normality: a concern with "standards", and among students a new fear of failure (Rothblatt, 1982). Such concerns demonstrate the new temporal orientation with the future as much as the past and the new evaluative concern with potential profit and loss - standards are to be "kept up", failure is a constant threat as each individual needs to keep "up to the mark", and even success may be relative failure (the "low First"). Constant examination and constant marking together maintain and maximise value from the present into the future, while they maintain and maximise disciplined work and workers along the same continuum. And they extend the power of writing by ultimately turning everything, even examination itself, into writing - which is the essence of the grammatocentric system.

The quiet revolution proceeds rapidly. By 1820 several colleges in the U.S.A. adopt varying marking systems, e.g. Princeton, Yale and West Point (Smallwood, 1935; Fleming, 1969). The monitorial systems, also without fanfare, start introducing marking and merit-demerit systems, and the Christian Brothers emend their method of punishment and reward. In some cases the derivation from a money of account is transparent since a fake currency is used to award the merits and subtract the demerits and this currency is physically paid to the students (Stewart, 1972, pp. 56-59) and is redeemable at specified times (e.g. the end of term) for prizes by those with sufficiently healthy balances. The Lancastrian monitorial system adopted this form of merit ticket around 1815 and the experimental Hill Top School in Birmingham began using dummy coins in the early 1820 s. Soon it was realized that the specie itself was superfluous (and possibly subversive through enabling a black market of dealings among pupils ).

By 1826 the American Journal of Education is publishing articles showing several variations on the accountability theme: William Fowle of the Boston Monitorial School (American Jour. nal of Education, 1826, p. 72) uses a "nominal currency called merits" and sets aside a sum each quarter for prizes: at the end of the quarter he totals all the merits earned, divides by the number of pupils and thus "the cash value of each merit is found"; each pupil's merit-demerit account is then worked out and if the balance is insufficient it is carried forward until a "good prize" can be earned. At G. F. Thayer's school in Boston each pupil's daily performance is recorded on his slate and the following day "the abstract of performance is transferred from the

\footnotetext{
numbers expressive of the rank on the several days ... in the term". Hence the less the sum the higher the overall rank. The absence of the mark is quite clear and in its absence there is no "objective" measure of self-worth for the individual. The lack of individual accountability is even more marked in the field of behavioural control. There is a Punishment Register. but no accumulation of mathematical demerits: instead a simple trust in the power of a simpie writing as a deterrent - the pupil conforming through "the bare assurance that his name will in the character of that of a delinquent be made to stand upon the face of a durable and more or less extensively published Register". Finally there is an Aggregate Progress Register. but this too is compelled to aggregate rankings and acts so that "the balance formed by the sum of the several acts of transgression compared with that of the correspondent manifestations of merit stands recorded"
} 
class slates . . to each boy's particular account" (American Journal of Education, 1826, p. 508). But in addition the mathematics have produced a norm: each task or lesson has the mark of four as a par, each day has a target which can be exceeded, and each week an aggregate mark above or equal to the target is a "good" report (pp. 563-564). A full quarter of thirteen "goods" merits a First-Rate Prize, twelve "goods" a Second Prize, and so on down to nine "goods", below which there is no prize.

This is a new kind of practice with no equivalent in earlier technologies of the human. Foucault at one point (1977, p. 181$)$ calls it "a transposition of the system of indulgences", but it is more than that. By bringing into play this new double sign within a field of accountingstyle texts, it produces a quality of power unknown to the world of indulgences. And it does so first within, so far as one can tell, educational institutions.

\section{DISCIPLINARY POWER, MANAGERIALISM AND COST ACCOUNTING}

It remains for us to suggest how the development of this new grammatocentric examinatorial system might be historically related to change in economic and financial organization. At a general level Foucault's theory of disciplinary power has a prima facie plausibility in relation to Alfred Chandler's thesis about the changes, beginning in the 1840 's, which led to the formation in the U.S.A. of modern corporate managerialism (Chandler, 1952; 1977). One finds first that surveillance has expanded by turning everything conceivable into writing: each job has clearly defined written functions, and all are located within chains of command which are diagrammed in organization charts; and second that judgement is constantly exercised through written reports and directives flowing up and down the chains of command reports and directives which constantly demand and process information which is couched in numerical form on all aspects of the enterprise. The surveillance is hierarchical and reciprocal (i.e. those at the top are reflexively responsible for shortcomings in the chain below them) and the judgement is exercised on the basis of the numbers. It is a system of constant, alphanumerically grounded, written examination, and as such structurally similar to the kinds of changes taking place in education a generation earlier.

However we would suggest that a specific historical linkage may exist between the educational innovations and the subsequent culture of managerialism (although we do so acknowledging that fuller analysis of other possible interrelations and explanations remains to be done). One remarkable feature of the development of modern managerialism is that it should take place in the U.S.A. Our suggestion is that particular attention should be paid to the role of West Point, which developed in the 1820's as a quite peculiarly grammatocentric educational institution. The connection between West Point and the culture of managerialism has been noted in general terms (Hall, 1982, p. 232). It was the only engineering school in the U.S. before the 1830's and many of its graduates worked as surveyors for canals and railroads: as Hall points out, among those who graduated before 1830 were "the presidents of the Hudson River, Panama, Philadelphia \& Baltimore, Burlington \& Missouri River and Central of Georgia lines ... the superintendents . . . of the Baltimore \& Ohio, Pennsylvania and other small lines .... (and) compared to the colleges, West Point supplied the greatest number of early railroads managers, followed most closely by Yale".

Chandler adds to this (1977, pp. 95-97) that two of his "pioneers of modern management", George W. Whistler of the Western and George McClellan of the Illinois Central, had military experience; however he does so while qualifying as follows: that these two "were the least innovative of the lot", that the military model had only an "indirect impact on the beginning of modern business management", and that "there is little evidence that railroad managers copied military procedures". Yet at the same time he singles out Whistler as the first to frame a managerial structure which fixed "definite responsibilities for each phase of the company's busi- 
ness, drawing solid lines of authority and communication for the railroad's administration, maintenance and operation": the structure (p. 98) had "two middle managers - the master of transportation and the master mechanic - and two top managers - the superintendent (originally the chief engineer, Whistler himself) and the president". And what he fails to stress (see Salsbury, 1967, p. 185) is that this sophisticated organization was drawn up and implemented in six weeks: following a head-on crash on the single Western line on 5 October, 1841 a committee including Whistler was appointed to produce administrative reform on 15 October, and it reported on 30 November. The question then becomes: how did Whistler produce his plan so quickly, bearing in mind that there was no business organization of any kind which would serve as a model?

The answer we suggest is West Point, where Whistler graduated in 1819 and then served as Assistant Teacher in Drawing in 1821-1822. ${ }^{11}$ Whistler therefore studied and taught under the new examinatorial regime at West Point instituted in 1817 by the so-called "Father of West Point", Sylvanus Thayer. Thayer borrowed directly from the Ecole Polytechnique its syllabus and text-books (originally taught in French), a teacher (Claude Crozet), and its mathematical grading system. But he quickly developed an institution sui generis, which went beyond the French model and became a fully "grammatocentric" organization.

By 1819 he had developed a marking system, which ran from 3 for perfect work to -3 for total failure (an interesting use of the negative as a kind of academic demerit), and a disciplinary network of books including a Weekly Class Report giving weekly mark totals, a Conduct Roll noting punishments (which around 1826 became a mathematical demerit book), an overall Merit Roll, a Progress Report singling out the worst students and a Register naming the best. In addition his personal style of administration became quintessentially grammatocentric. In
December 1821, while Whistler was teaching there, there was (Fleming, 1969, p. 50) a major riot with the Mess Hall set ablaze and a cannon (which failed to go off) loaded and pointed at Thayer's residence. His response was to reorganize the harracks under the constant surveillance of resident tutors who filed daily and weekly reports not to Thayer but to his secondin-command, the commandant. Thereafter Thayer became a ghostly presence, hardly ever seen by the cadets. There was a chain of command leading up from senior cadet through the tutors to the commandant, while Thayer himself became a separate, complementary locus of authority who "entered the picture only as a court of last resort" (Fleming, 1969, p. 50). He became the model of the "grammatocentric man". His orders were issued in writing and relayed by other intermediaries; even dismissals from the academy were issued in this way and then read out at parade by the officer of the day as a list of "resignations accepted, very much to the astonishment and dismay of those whose names were mentioned" (Denton, 1964, p. 180 ). For himself, Thayer knew the cadets principally through the files, which were kept meticulously by his personal clerk. He disconcerted those summoned to formal interviews by knowing them without personal contact - in fact through reading off slips prepared and pasted inside the pigeon-holes on his desk: a kind of VDU read-out before the computer (Fleming, 1969, p. 48).

Thus the organizational structure and the meticulous system of accountability which made up Whistler's 1841 blueprint for managerial organization can be traced in a distinct line of descent from his own experience as student and officer at West Point. (It is hard to see where else he could have encountered such a system, since after leaving West Point he worked exclusively as a surveyor and a railway engineer.) So we suggest that it is wrong to see him as "least innovative", and to view the military procedures as irrelevant. True, they were not military proce-

\footnotetext{
"Here is one of those little ironies of textual history - our W'histler is in fact "Whistler's Father".
} 
dures per se, for they were not procedures found in the army at large but disciplinary pedagogic procedures implemented solely within the military academy; and Whistler certainly only laid a foundation which others were to transform into an autonomous managerial discourse whose origins would subsequently be obscured. But he forms, it appears to us, the vital point of contact between the pedagogic world and its system of human accountability and the subsequent elaboration of a new kind of accountability and efficiency within business structures.

We do not wish to retrace well-known ground concerning the contributions of Daniel McCallum and the development of the organization chart, or Henry Varnum Poor and the systematic accumulation and analysis of business statistics, or finally Albert Fink and the construction of an easily-workable system of cost accounting (Chandler, 1977, pp. 103-121). Only to point out that this new general discourse has its specific history - a history which can be read in terms of the analysis which we have laid out here. It has recently been suggested (Miller \& O'Lcary, forthcoming) that accounting in this century has come to operate as part of a disciplinary system of efficiency; we would agree that this is so, only adding that its origin lies in the period 1810-1830. They point out "in its most developed mode such a form of power consists in an auto-regulation by people of their own lives." By 1823 Thayer had instituted the West Point Honor code, based on daily self-reporting of infractions in what became known as the Skin List, i.e. a system where the mutual surveillance is such that self-discipline is both the prudent and the virtuous path to follow. That is the essence of the new power.

Once the link was made, the potential of accounting for calculating the costs of different divisions could be exploited. The aim is now constant profitability, and it is expressed in a discourse which assumes that the values both of products and of persons must be calculated. So McCallum proposes his costing system in 1855 in clear examinatorial tones, saying: "it will show the officers who conduct their business with the greatest economy, and will indicate, in a manner not to be mistaken, the relative ability and fitness of each for the position he occupies ... and it is believed, will have the effect of exciting an honorable spirit of emulation to excel" (quoted by Chandler, 1977, pp. 115-116). It is true that Fink's detailed development and implementation in the 1870 s of McCallum's proposals was premissed equally on the "economic decision making" need for knowledge of the costs of carriage of different clases of freight as a basis for rate-making (Chandler, 1977, p. 117), but Fink's success can itself hardly be explained on purely economic grounds. The economists soon showed such an application to be "impracticable" (Wells, 1978, pp. 114-118) (just as "costs per ton of coal mined" may provide a misleading guide to economic choices in the NCB today), and so we suggest that further evaluation of the manner in which such systems provided an examinatorial apparatus for extending a system of human accountability highlighting control over, and self-control by, managers may provide a fuller understanding of cost accounting's success (cf. Noble, 1977, pp. 261 ff.).

\section{DISCIPLINARY POWER AND THE PROFESSIONALIZATION OF ACCOUNTANCY}

We close with a final, more general, observation. We have concentrated here on the specific power-knowledge interrelations between cducation and accounting. However there is a more general effect which the new examinatorial system arguably had upon the social organization of knowledge and power, in the construction of the modern professions (of which accounting is manifestly one). It has recently been suggested that Foucault's model of the disciplines may extend and deepen the insights provided by professionalization theory (Goldstein, 1984, esp. pp. $174 \mathrm{ff}$.). Academic disciplines form the basis for the bodies of esoteric knowledge whose mastery "is the indispensable qualification for practice" in the various modern professions; and professions maintain and reproduce themselves in two further ways - monopoly of the exclusive right to recognize professional competence "in 
the domain to which its body of knowledge refers", and autonomy of control "by the profession over its work, including who can legitimately do that work" (Goldstein, 1984, p. 175).

In all these aspects the new disciplinary organization of educational practice is writ large. First the nineteenth century saw the development of the modern university, offering a wide and ever-increasing range of specialist degrees, legitimated by written, marked examinations both at undergraduate and graduate levels. This constituted the development of the modern network of academic disciplines, which in Goldstein's analysis is the precondition for the development for the modern network of professions. Secondly, it is instructive to note how professions came to appropriate both monopoly over competence and autonomy of control. As Foucault himself showed in The Birth of the Clinic (1973, pp. 76 ff.), even in an old-established profession like medicine this was done by the imposition of new rigorous academic examination to be undertaken either within the elite medical school (in France in the Ecoles de Santé) or under the auspices of some analogous institution (the hospital). Having thus established monopoly over competence via examination, autonomy of control could legitimately be claimed by the newly-validated professional body

This same process can be seen taking place in the development of the profession of accountancy during the latter half of the nineteenth century. Texts on accountancy become considerably more detailed and weighty, offering a rec. ognizably academic "body of knowledge". In the I.S.A. from the 1880 's accountancy is taught in graduate business schools and is made the chief component of the course at the New York University graduate school which opens in 1896 (Monroe. 1911 , article on Accountancy Education ). In Britain first steps towards autonomy of control are taken by leading members of the first informal fluid partnerships, which begin to appear around 1850 (Jones, 1981, pp. 33-34) with the establishment of Harding \& Pullein, Turquand \& Edwards and Turquand, Youngs \& Co. By $18^{70}$ there is the Incorporated Society of
Liverpool Accountants out of which evolves an umbrella regulatory body, the Institute of Accountants (p. 67), formally incorporated in 1880 out of various local bodies. This Institute could then deal with those who in Frederick Whinney's words "thought they had nothing whatever to do to become accountants but to put up a plate and designate themselves as such in order to become rich men": i.e. what the fathers had done was not to be open to the rivals of the sons to do. Then all that was left to do was to establish a monopoly over competence by taking over the written, graded examination with its power to control entry, set standards and simultaneously validate the status of those who passed.

This was not all "bad": indeed disciplinary power is itself not all "bad", it is simply different and more totalizing in its effects. So one of the differences in the new examinatorial mode was to open a door for the able and non-wealthy into the new-style profession. Lawrence Dicksee was one of the first to qualify, in 1896, via the examination route (Kitchen \& Parker, 1980, pp. 5354). And by 1906 the circles had been closed and the full implications of the new explicit relation between accounting and examination made clear in the discourse of accountancy, when Arthur Cutforth produced in his Audits representative examination questions, and in addition wrote his Early Stages of Preparation for the Accountancy Papers of the Intermediate.

Thereafter, as Ann Loft shows (1986), wouldbe professional groups like the aspiring costs accountants turned almost automatically to examinatorial legitimation in order to create their own separate professional identity.

\section{CONCLUSION}

We suggest that further exploration of the interrelationships between the histories and practices of education and of accounting will yield further insights into the nature of the power-knowledge systems that they construct, and thereby enlarge or refocus the debate on the roles and value of accounting. In this paper we 
have concentrated on the historical significance of the examination as a technology of power. Further comparison is needed of the present-day roles of accounting in relation to business and organizational activity with those of the examination in relation to education [for example by doing a discourse analysis of possible interrelationships underlying managerial perceptions of accounting systems (Hoskin, 1985) or by exploring the intervention of the State in regulating accounting and educational standards].

There can be no doubt of the extraordinary power of the disciplinary system as we have outlined it - but yet it remains a questionable regime of power-knowledge practices. While examinatorial technologies, both in education and accounting, have enormous influence in the exercise of social control (in defining success and failure; in allocating and awarding access to resources and power; etc. ), their claims to provide knowledge, by quantification of human performance, are nevertheless extremely problematic and open to fundamental theoretical challenges in terms of the validity, reliability and relevance of the knowledge they provide (e.g. Wigdor \& Garner, 1982; Macve, 1981, ch. 9).

Yet modern societies cannot now envisage how they could organise themselves without these techniques and it is impossible for us, even while recognising their implications for power relations, to stand outside the regimes of knowledge they produce. Having invented them we cannot either avoid or simply transcend them: we are bound at best it seems to trying to improve them, either by reducing their inadequacies and arbitrary effects as far as possible, or by extending their number and scope.

\section{BIBLIOGRAPHY}

American Joumal of Education, Vol. 1 (1825-1826).

Artz, F., The Development of Technical Education in France, 1500-1850 (Cambridge, MA, 1964).

Baldwin, J., Masters at Paris from 1179 to 1215: A Social Perspective, in Benson, R. \& Constable, G. (eds)

Renaissance and Renewal in the Twelfth Century pp. 138-172 (Oxford: Clarendon, 1982)

Bentham, J., Chrestomathia (London, 1816).

Burchell, S., Clubb, C., Hopwood, A., Hughes, J. \& Nahapiet, J., The Roles of Accounting in Organizations and Society, Accounting, Organizations and Society (1980) pp. 5-27.

Chandler, A., Henry Varnum Poor, Philosopher of Management, in Miller, W. (ed.) Men in Business pp. 254-285 (Cambridge, MA: Harvard University Press, 1952).

Chandler, A., The Visible Hand (Cambridge, MA: Harvard University Press, 1977).

Clanchy, M., Moderni in Education and Government in England, Speculum (1975) pp. 671-688.

Cohen, P., A Calculating People (Chicago: University of Chicago Press, 1983)

Denton. E., The Formative Years of the U.S. Military Academy, Ph.D. dissertation, Syracuse University (1964).

Derrida, J., Of Grammatology (Baltimore: Johns Hopkins, 1976).

Douglas, D. \& Greenway, G. (eds) English Historical Documents, Vol. 2 (London: Eyre Methuen, 1981 ).

Drew, J. S., Manorial Accounts of St. Swithun's Priory, Winchester, English Historical Review (1947) pp. 20-41.

Durkheim, E., The Etolution of Educational Thought (London: Routledge \& Kegan Paul, 1977).

Eisenstein, E., The Printing Press as an Agent of Change (Cambridge: Cambridge University Press. 1979).

Evans, G., From Abacus to Algorism: Theory and Practice in Medieval Arithmetic, British Journal for the History of Science (1977) pp. 114-131.

Evans, G., Old Arts and New Theology (Oxford: Oxford University Press, 1981)

Finley, M., The Ancient Ecortomy 2nd. edn (London: Hogarth, 1985).

Fleming, T., West Point (New York: Morrow, 1969).

Foucault, M., The Order of Things (London: Tavistock, 1970).

Foucault, M., The Birth of the Clinic (London: Tavistock, 1973).

Foucault, M., Discipline and Punish (London: Allen Lane, 1977).

Foucault, M., The History of Sexuality, Vol. 1, An Introduction (London: Allen Lane, 1979). 
Foucault, M., The Order of Discourse, in Young, R. (ed.) Untying the Text pp. 48-78 (London: Routledge \& Kegan Paul, 1981 ).

Foucault, M., The Subject and Power, Critical Inquiry (1982) pp. 777-795.

Foucault, M., L'Histoire de la Sexualité, Vol. 2: L'Usage des Plaisirs (Paris: Gallimard, 1984a).

Foucault, M., L'Histoire de la Sexualité, Vol. 3: Le Souci de Soi (Paris: Gallimard, 1984b).

Goff, J. le, La Naissance du Purgatoire (Paris: Gallimard, 1981).

Goldstein, J., Foucault among the Sociologists: the 'Disciplines' and the History of the Professions, History and Theory ( 1984 ) pp. 170-192.

Goldthwaite, R., Private Wealth in Renaissance Florence (Princeton: Princeton University Press, 1968).

Griffiths, R., Public and Private Bureaucracies in England and Wales in the 15 th century, Transactions of the Royal Historical Society (1980) pp. 109-130.

Hall. P.. The Organization of American Culture, 1700-1900 (New York: New York University Press, 1982 ).

Haskins, C., The Abacus and the Exchequer, in Haskins, C. (ed.) Studies in the History of Medieval Science pp. 327-335 (Cambridge, MA: Harvard University Press, 1924).

Hopwood, A.. The Archaeology of Accounting Systems, Accounting, Organizations and Society (forthcoming).

Hoskin, K., The Examination, Disciplinary Power and Rational Schooling, History of Education (1979), pp. 135-146.

Hoskin, K. Cobwebs to Catch Flies: Writing (and) the Child, unpublished paper, University of Warwick (1984).

Hoskin, K, A Comment on 'Accounting as Discipline' by John Roberts and Robert Scapens, presented at Interdisciplinary Perspectives on Accounting Conference, University of Manchester, 8-10 July (1985).

Hume. L. The Development of Industrial Accounting: the Benthams' Contribution,Joumal of Accounting Research (1970) pp. 21-33.

Hyde, J., Some uses of literacy in Venice and Florence, Transactions of the Royal Historical Society (1979) pp. 109-128.

Johnson, C. et al. (eds.) Richard Fitz Nigel's Dialogus de Scaccario (Oxford: Clarendon Press, 1983 ).

Jones, E., Accountancy and the British Economy, 1840-1980 (London: Batsford. 1981 ).

Kitchen, J. \& Parker, R., Accounting Thought and Education (London: Institute of Chartered Accountants in England and Wales, 1980).

Landes, D.. Revolution in Time: Clocks and the Making of the Modern World (Cambridge, MA: Belknap Press, 1983).

Latham. R.. Dictionary of Medieval Latin from British Sources, fasc. II (London: Oxford University Press, $1981)$.

Leone. A. Some Preliminary Remarks on the Study of Foreign Currency Exchange in the Medieval Period, Joumal of Economic History (1983) pp. 615-629.

Loft. A., Towards a Critical Understanding of Accounting: The Case of Cost Accounting in the U.K, 19141925, Accounting, Organizations and Society (1986) pp. 137-169.

McKendrick, N., Josiah Wedgwood and Factory Discipline, The Historical Journal ( 1961 ) pp. 30-55

McReynolds. P. \& Ludwig. K. Christian Thomasius and the Origin of Psychological Rating Scales, Isis (1984) pp. 546-553.

Macve, R., A Conceptual Framework for Financial Accounting and Reporting: the Possibilities for an Agreed Structure, (London: Institute of Chartered Accountants in England and Wales, 1981 ).

Macve, R. Some Glosses on 'Greek and Roman Accounting', History of Political Thought (1985) pp. 233264

Miller, P. \& O'Leary, T., Accounting and the Construction of the Governable Person, Accounting, Organizations and Society (forthcoming).

Monroe, P., A Cyclopaedia of Education (New York: Macmillan, 1911 ).

Morgan. E.. The Gentle Puritan: A Life of Ezra Stiles (New Haven: Yale University Press, 1962 ).

Murray. A., Reason and Society in the Middle Ages (Oxford: Clarendon Press, 1978).

Noble. D.. America by Design: Science, Technology, and the Rise of Corporate Capitalism (New York. Knopf, 1977).

Noke. C. W'.. Accounting for Bailiffship in Thirteenth Century England, Accounting and Business Researcb (1981) pp. 137-51

Orme, N., English Schools in the Middle Ages (London: Methuen, 1973).

Oschinsky, D., Walter of Henley and Other Treatises on Estate Management and Accounting (Oxford: 
Oxford University Press, 1971).

Pollard, S., The Genesis of Modern Management (London: Arnold, 1965).

Rich, E. \& Wilson, C. (eds.), Cambridge Economic History, Vol. 5. (Cambridge: Cambridge Lniversity Press. 1977).

Richardson, H., Business Training in Medieval Oxford, American Historical Review (1941) pp. 259-280.

Roover, R. de, Money, Banking and Credit in Medieval Bruges (Cambridge. MA: Medieval Academy of America, 1948).

Roover, R. de, The Rise and Decline of the Medici Bank, 1397-1494 (Cambridge, MA: Harvard Liniversity Press, 1963).

Roover, R. de, Business, Banking and Economic Thought (Chicago: University of Chicago Press, 1974).

Rothblatt, S., Failure in Early 19th-Century Oxford and Cambridge, History of Education (1982) pp. 1-21.

Rouse, R. \& Rouse, M., Preachers, Florilegia and Sermons (Toronto: Pontifical Institute of Medieval Studies. 1979).

Rouse, R. \& Rouse, M., Statim Invenire: Schools, Preachers, and New Attitudes to the Page, in Benson, R. \& Constable, G. (eds) Renaissance and Renewal in the Twelfth Century pp. 201-228 (Oxford: Clarendon Press, 1982)

Saenger, P., Silent Reading: its Impact on Late Medieval Script and Society, Viator (1982) pp. 367-414.

Salle, J.-B. de la, The Conduct of the Scbools (tr. de la Fontainerie) (New York: McGraw-Hill, 1935).

Salmon, D. (ed.) The Practical Parts of Lancaster's Improvements and Bell's Experiment (Cambridge: Cambridge University Press, 1935).

Salsbury, S., The State, the Investor, and the Railroad: Boston \& Albany, 1825-1867 (Cambridge. MA: Harvard University Press, 1967).

Smallwood, M., An Historical Study of Examinations and Grading Systems in Early American Universi. ties (Cambridge, MA: Harvard University Press, 1935)

Southern, R. The Schools of Paris and The School of Chartres, in Benson, R. \& Constable, G. (eds) Renaissance and Renewal in the Twelfth Century pp. 113-137 (Oxford: Clarendon Press, 1982).

Ste. Croix, G. de, Greek and Roman Accounting, in Littleton, A. and Yamcy, B. (cds) Studies in the History of Accounting (London, 1956) pp. 14-74.

Stewart, W., Progressives and Radicals in English Education, 1750-1970 (London: Macmillan, 1972).

Stone, E., Profit-and-Loss Accountancy at Norwich Cathedral Priory. Transactions of the Royal Historical Society (1962), pp. $25-48$.

Thompson, E., Time, Work-Discipline and Industrial Capitalism, Past and Present (1967) pp. 56-97.

Udovitch, A., Bankers without Banks: the Islamic World, in Lopez, R. (ed.) The Dawn of Modern Banking (New Haven: Yale University Press, 1979).

Ullmann, W., The Growth of Papal Government in the Middle Ages (London: Methuen. 1970).

Wells, M., Accounting for Common Costs (Urbana-Champaign, IL: Center for International Education and Research in Accounting, 1978).

Wigdor, A. \& Garner, W. (eds), National Research Council (US), Committee on Ability Testing, Ability' Testing: Uses, Consequences and Controversies (Washington. DC: National Academy Press, 1982 ).

Yamey, B., Accounting and the Rise of Capitalism: Further Notes on a Theme by Sombart, Journal of Accounting Research (1964) pp. 117-136

Yamey, B., Some Topics in the History of Financial Accounting in England, 1500-1900, in Baxter, W. \& Davidson, S. (eds), Studies in Accounting (London: Institute of Chartered Accountants in England and Wales, 1977), pp. 11-34. 